\title{
ORIGINAL PAPER \\ End-of-Life Decision Making in Orthodox Judaism: The Case of the 1977 Conjoined Twins
}

\author{
Joshua Cypess ${ }^{1}$ (D) \\ Published online: 25 May 2019 \\ (c) Springer Nature B.V. 2019
}

\begin{abstract}
In 1977, conjoined twins were born to an Orthodox Jewish family in Lakewood, New Jersey; they were treated at Children's Hospital in Philadelphia. Following legal deliberations in the American court system, as well as religious deliberations within the Orthodox Jewish, Protestant, and Catholic communities, the twins were separated by surgeon C. Everett Koop, who later became Surgeon General of the United States. Evaluation of the medical decision making process in the 1977 case illustrates the distinctly legal nature of Orthodox Jewish discourse-a feature that sets it apart from Protestant, Catholic, and secular ethics. This legal character of Orthodoxy had been highlighted a decade earlier, in a report issued by a panel that had been convened to study the different approaches to conjoined twins among Jewish, Protestant, and Catholic authorities. Close examination of that report, and of the circumstances of the 1977 case itself, bring to the fore the legal nature of the Orthodox Jewish procedures determining the medical outcomes of the conjoined twins. The distinctive nature of the Jewish approach is thrown into relief even further by comparison with the differing approaches among Catholic, Protestant, and secular authorities and medical caregivers. Following an elaboration and explication of the report and the 1977 case in which I examine the important contrasts between the adherents to different traditions and legal systems, I explore their broader implications for understanding the cultures of Jewish medicine in an increasingly complex scientific and technological landscape.
\end{abstract}

Keywords Conjoined twins · Orthodox Judaism · C. Everett Koop · Medical sociology $\cdot$ End-of-life care $\cdot$ Jewish law

Joshua Cypess

cypess@cypess.com

1 Highland Park, NJ, USA 


\section{Introduction}

In her book How Judaism Became a Religion, Leora Batnitzky identifies aspects of Judaism that set it apart from other religions, and that persist even today as essential components of Jewish culture-especially in communities that identify as Orthodox, or as adhering to the system of Jewish law (halakhah) writ large (Batnitzky 2011). Batnitzky argues that Judaism — both in its premodern manifestation and today-is not only a religion, but also a culture that encompasses three dimensions: religion, ethics, and law. In this essay, I will explore one manifestation of this distinctive nature of Judaism in a case study pertaining to making medical decisions at the end of life. I argue that the picture of Judaism Batnitzky presents continues to shape Jewish cultural discourse regarding medical issues. As I will show, the profile of Judaism as an amalgam of religion, ethics, and law informs reactions on the part of Jewish patients, rabbinic authorities, and medical caregivers to such an extent that it often comes into sharp conflict with the secular view of medical issues in the United States and with the views of other religions.

In 1977, conjoined twins were born to an Orthodox Jewish family in Lakewood, New Jersey and later treated at Children's Hospital of Philadelphia (CHOP). Following legal deliberations in the American court system, as well as religious deliberations within the Orthodox Jewish, Protestant, and Catholic communities, the twins were separated by surgeon C. Everett Koop, M.D., who later became Surgeon General of the United States. ${ }^{1}$ An evaluation of the medical decision-making process in the 1977 case illustrates the distinctly legal nature of Orthodox Jewish discourse. This legal character had been highlighted a decade earlier in a report issued by a panel convened to study the different approaches to conjoined twins among Jewish, Protestant, and Catholic authorities. A close examination of that report, and of the circumstances of the 1977 case bring to the fore the legal nature of the Orthodox Jewish procedures that determined the medical outcomes of the conjoined twins. The distinctive nature of the Jewish approach is thrown into relief even further by comparing it with the differing approaches among Catholic, Protestant, and secular authorities and medical caregivers. In this article, I explicate and elaborate on the panel's report and the 1977 case as I examine the important contrasts among adherents to different traditions and legal systems. I also explore the broader implications of this case for understanding the cultures of Jewish medicine in an increasingly complex scientific and technological landscape.

My approach to this study is an interdisciplinary one. My aim is to understand the complex interactions of patients, their families, health-care providers, and religious authorities-groups that are often in the grip of competing and sometimes conflicting influences. As a result of this complexity, my discussion and the sources upon which I draw are necessarily diverse. The topics I engage with include bioethics,

\footnotetext{
1 For background on the medical history of conjoined twins, as well as cultural attitudes toward such cases, see Aird (1954), Dominus (2011), and Wyszynski (2001). This article is based on a chapter of Joshua Cypess, Jewish Medical Culture: Case Studies in End-of-Life Decision Making (Doctoral dissertation, Brandeis University, 2015).
} 
Jewish law, medical sociology, comparative religion, and history. My sources include primary historical data (for example, newspaper articles, autobiographical accounts, and interviews), religious manifestos, and literature from the Jewish legal tradition (including the Talmud and Orthodox Jewish legal responsa). In bringing these methodologies and sources to bear on one another, my goal is to analyze the complexity of the medical experience in Judaism in the modern world. Although the case that I examine here represents an extremely rare occurrence, I argue that the extreme and difficult circumstances it manifests expose those complexities in a unique way. The perplexing issues and fault lines uncovered through a consideration of this case will lead to a more nuanced understanding of the interactions among medicine, religion, law, and ethics.

\section{The 1967 Panel on Conjoined Twins}

The 1977 case, which I will describe in detail below, involved an Orthodox Jewish couple whose twin baby girls were born conjoined. It was clear that both babies would die if they were not surgically separated; however, the surgery would result in the death of one of the babies. The fraught ethical, legal, and religious issues involved led the parents to consult with rabbinic authorities-ultimately, with Rabbi Moshe Feinstein, an Orthodox rabbi who was his generation's most highly respected posek, or "decisor", a legal scholar who decides halakhah (Jewish law) in cases where previous decisions are inconclusive or where no halakhic precedent exists. The surgeon in the case, C. Everett Koop, was a devout Protestant, and the nurses at the hospital were predominantly Catholic; for them, too, faith was a major factor in their decisions about how to proceed and provide care for the conjoined twins. Ultimately, Koop performed the surgery, which resulted in the immediate death of one of the babies. The second baby later died of hepatitis B, which she had contracted during a blood transfusion.

The 1977 case was prefigured in striking ways by the report of a committee formed in 1967 to evaluate the ethical and moral issues raised by the question of whether or not to separate the twins. Writer C. K. Pepper, who was a member of the panel, later wrote a report summarizing the panel's work- "Ethical and Moral Considerations in the Separation of Conjoined Twins". ${ }^{2}$ In his 1967 report, Pepper noted that the topic of medical ethics - a field still in its infancy at the time-was seen as the domain of the clergy; therefore, the panel invited members of the clergy to participate in the discussion along with the medical practitioners. The fourteen members of the panel included distinguished physicians, psychologists, and clergymen

\footnotetext{
${ }^{2}$ In a 2009 article (9 fn. 5), historian of science Elena Aronova explains that the rise of the field of medical ethics occurred at that time in response to a number of significant events: “...the Thalidomide scandal following the identification of the side effects of this drug in 1961, Henry Beecher's 1966 exposé that revealed the mass violations of the principles of beneficence and informed consent, and the revelation of the Tuskegee Syphilis Experiment in 1972 [i.e. the Tuskegee Study of Untreated Syphilis in the Negro Male]" [for more about the impact of medical scandal on the creation of the field of medical ethics, also see Gamble (1997, 2006), and Lepicard (2009)]. See also Beecher et al. (1984).
} 
from what were then considered the three major religions in the United States: Protestantism, Catholicism, and Judaism. Only one of the members of the panel was a rabbi: Conservative Jack Segal, whose ordination was from the ultra-Orthodox Mesivta Yeshiva Rabbi Chaim Berlin in Brooklyn. ${ }^{3}$

Pepper's essay is significant because it is the earliest scholarly publication on this topic that explores diverse religious-ethical viewpoints, and it provides an early view of what would later emerge as relatively consistent positions in cases of conjoined twins. The paper has two sections, as indicated by the report's subtitle: "A Summary of Two Dialogues Between Physicians and Clergymen". The first section, which covers psychological considerations, focuses exclusively on the domain of the physicians. ${ }^{4}$ The second section offers theological considerations, and includes three subsections entitled "The Protestant View" (130-133), "The Catholic Position" (133) and "The Jewish View" (133-134). ${ }^{5}$ The methodologies of the three religions in the 1967 panel highlight the divergent approaches of the different religions as a whole: The Catholic and Protestant discussions are philosophical or broadly ethical in nature, while the Jewish discussion is clearly framed as engaging a body of texts and the distinctive legal tradition constituted by those texts and their interpreters. This early 1967 discussion thus provides preliminary evidence that medical discourse in Judaism operates within a legal framework. ${ }^{6}$

The Protestant view of a hypothetical case of conjoined twins-eerily, a case that prefigures the actual 1977 case in numerous respects, including its set of "thoracopagus twins in whom a single heart is shared"-is described as follows:

In regard to the ethical considerations in the sacrifice of one conjoined twin to save the other twin, when both seem certain to die if no separation is achieved, Protestant ethics seem to pose no obstacle to the surgical act; the disjoining act should be viewed more as a positive act of saving or preserving than as a negative act of destroying life. The emphasis is that life is more than quantity of days; that life is measured by quality as well as longevity" (Pepper, 130).

\footnotetext{
3 According to the website of Congregation Beth Yeshurun, a Conservative synagogue in Houston, Texas, Segal, who is now the shul's rabbi emeritus, “...came to the synagogue in 1965 as Associate Rabbi to Rabbi William S. Malev for 8 years, then as Senior Rabbi of the congregation for 23 years until he retired in August 1996. Prior to coming to Houston, Rabbi Segal held rabbinical positions in Homestead and McKeesport, Pennsylvania; and in Portland, Oregon. Rabbi Segal was ordained a Rabbi at Mesivta Rabbi Chaim Berlin in 1954. Prior to that, he earned undergraduate degrees in Physics and Mathematics at New York University and the University of Pittsburgh, respectively; and advanced degrees at Oregon State University, Hebrew Union College, and the University of Houston" (see Anonymous (XXXXa) http://www.bethyeshurun.org/staff_details.php?id=6, accessed August 14, 2016).

4 In retrospect, the psychological perspectives expressed in Pepper's essay seem disturbing, especially in their unabashed acknowledgement that conjoined twins who survive the procedure of separation are seen to be almost monstrous (see Crane 2012 for a Jewish response to this kind of bias).

5 These three categories support and follow the famous division of Will Herberg's Protestant, Catholic, Jew (1955).

${ }^{6}$ For a discussion of Islamic approaches to the separation of conjoined twins, see Raffensperger (1997, p. 250).
} 
By contrast, the Catholic view expressed discomfort with the surgeon making an active choice to cause the death of one baby in favor of the other. As we will see, this attitude manifested itself in 1977 in the discomfort expressed by members of the Catholic nursing staff when Koop performed the surgery.

As a guide in arriving at a mature moral judgment, Catholic moral theologians in such cases employ the principle that an innocent human life cannot be directly suppressed.... This principle in turn is based on the fundamental fact that every human being derives his right to life, not from his parents, or from society, but directly from God. In the situation under consideration, the surgical procedure would involve basically the allocation of the common heart to one twin ... [yet] no matter what benefits may accrue to one twin, the indisputable fact remains that one twin is necessarily killed in the process of being surgically deprived of a heart. From this point of view, the Catholic moral theologian would have to render the judgment that it would not be morally permissible to separate conjoined twins where such separation would certainly result in the death of one or both twins. (133)

Within the theological portion of the article, it is telling that the section on the Jewish view is the only one that contains textual references. The pervasiveness of this text-based approach is evident in the following excerpt:

An infant younger than 31 days of life lacks human status in respect to the redemption of the firstborn (Yoreh Deah 205:11, 12); in that he does not exempt a widowed mother from the duty of contracting or dissolving the levirate bond (Even Ha' ezer 156:4); in that expiring, the family does not tear a rent in the garment for him (Yoreh Deah 311:30); and in that one does not mourn for him (Yoreh Deah 374:8). (Pepper, 134)

The references here are to portions of the Shulchan Aruch (a sixteenth-century code of Jewish law), altogether the section on the Jewish view contains nearly two dozen references to legal works. This textual-legalistic tone in the section on the Jewish approach stands in contrast to the approach of the Protestant view, which contains no references at all. Even the section outlining the Catholic view contains no legal citations, despite the long-standing tradition of Canon law and its ecclesiastical/legal tradition. ${ }^{7}$

Segal's contribution to the 1967 report follows a structure that echoes that of Jewish responsa literature: He begins by reporting the opinions of other authorities, focusing on four with whom he consulted. He then engages with the legal literature that informed those earlier opinions and his own understanding, and he concludes with his final decision. This structure contrasts with that of the other contributions to

\footnotetext{
7 By contrast, in the context of the 1977 case, the Reverend Monsignor Francis X. Meehan, the Catholic priest who gave religious counsel to the nurses assigned to the case at Children's Hospital, wrote a full explanation of his reasoning. This document (Meehan 1978), allows us to view the priest's ecclesiastical/ legal deliberation on this topic. However, as I will argue, even this document reads like a philosophical discussion rather than a legal one: The principles upon which the priest based his decision appear to emerge from a divine source, rather than from a system of logic or reason.
} 
the report. In first presenting the conflicting views of other rabbinic scholars, Segal situates his contribution within a multivocal legal tradition to which he contributes his own (tie-breaking) decision. As Segal explains, "Of the four [unidentified] Jewish scholars asked for opinions, two favored separation of the twins, even though it was quite obvious that one would die, and two stated that traditional Judaism would not permit this act" (133). Thus, while the contributions by representatives of the other two religions in the report present an unambiguous conclusion, the Jewish section reports multiple opinions. The end of Segal's contribution presents his own ruling: "In summary, the participating rabbi felt that in a situation where conjoined twins are joined in such a manner that if they were not separated they would both die, and if they were younger than 31 days of age, and if the chance of survival for one of the twins were better than [that of] the other, Judaism would require a surgical separation be performed". (134)

This contrast between the legal character of the section of this report dealing with the Jewish tradition and the perspectives of the Protestant and Catholic sections is understandable in light of Leora Batnitzky's explication of modern Judaism. As noted above, Batnitzky's How Judaism Became a Religion traces Judaism from its emergence as a religion to the Enlightenment philosophy of Moses Mendelssohn, who sought to set Judaism on an equal footing with Christianity, thus allowing Jews to coexist under the umbrella of a secular nation. Premodern Judaism viewed Jewish law and Jewish ethics as one and the same thing, in contrast to secularist philosophers of the Enlightenment, who introduced a theoretical framework that distinguished among the disciplines of religion, morality, and law, each of which came to be thought of as a separate field. Batnitzky explains it this way:

In the case of Judaism, the category of religion, defined as a sphere of life separate from other spheres (such as politics, morality, and science, just to name a few), simply does not quite fit. Modern Jewish thought may be understood as the story of the attempt by Jewish thinkers to fit Judaism into this category and the rejection of this effort, which in turn inspires subsequent attempts to place Judaism into yet another category, such as culture or nationality, which as we have seen, does not quite fit either. $(190)^{8}$

This passage explains the distinctly legal aspects of Jewish methodology and thought on complex medical cases. The system of Jewish law (halakhah) is primarily a legal system, in which a rabbinic authority (posek) rules about case law based on legal precedents dating back to the time of the Talmud and, indeed, to the Bible itself. Batnitzky is not alone in making this distinction explicit; her conclusion is

\footnotetext{
8 Batnitzky's work presents the clearest articulation of this concept. Many others have asserted similar points; see Blidstein (2009), Elon (1994), Jospe et al. (2007), Magid (2005), Moodie et al. (1993), and, for a historical perspective (Sarna 1990). For current expressions of the unity of halakhah as a seamless combination of law, religion, and ethics/morality, see Brand (2010), Breitowitz (1996), Broyde (2000), Crane (2012, 2013), Englard (1988), Falk (1994-1995), Fishbane (1990), Glick (2008), Goldsand et al. (2001), Green (2005), Jackson (1987, 2008), Lamm (2007), Lasker (n.d.), Levene (2005), Levin (1987), Lichtenstein (1975), Putnam (2005), Resnicoff (2006), Sagi (1994), Sinclair (1992), Teutsch (2005), Washofsky (2007, 2012), Weingarten (2002), Wenger (1998), and Woolf (2009).
} 
strongly supported by Sullivan's (2005) article presenting a general overview of the interplay between law and religion:

In the context of the modern West, however, law, religion, and ethics have been progressively differentiated, being understood, both socially and rhetorically, to inhabit different domains... Western observers may distinguish institutions and ideas that parallel modern secular legal ideas and institutions but, by and large, law in premodern societies was, to a greater or lesser degree, subsumed within and served what might be termed a religious worldview. (107)

Because law and morality are intertwined in Judaism, halakhah can refer to multiple domains within the Enlightenment system. Michael J. Broyde, a specialist in the intersection of religion and the law, also emphasizes the nature of Judaism as an amalgam of religion, law, and ethics:

The term halakhah (in Hebrew, "the way" or "the path") is usually interpreted to refer only to Jewish law as it relates to practical observance. However, it encompasses all of Judaism; law, theology, and ethics are all encapsulated in "the way" a Jew must observe. Thus, halakhah can be understood to refer to "law" in its largest definition: a structure in which internal faith as well as external conduct is measured and governed. (2000, pp. 25, 26)

While there has long been a debate about whether halakhah is or is not inherently moral, ${ }^{9}$ the debate, according to Batnitzky's historical explanation, should be seen as a particularly modern invention, because, before the Enlightenment, religion and morality were considered to be one and the same thing. ${ }^{10}$

Some scholars of Jewish medicine and medical ethics have observed the effects of this premodern legal character of Judaism in contemporary Jewish practice. Benjamin Freedman (1999), a Canadian bioethicist, made this distinction in his book, Duty and Healing: Foundations of a Jewish Bioethic. The book deals with the distinctions between "duty" (which he identifies as a Jewish concept) and "rights" (a post-Enlightenment and American concept), and the implications of this distinction in contemporary health care. Freedman cites the legal historian Cover (1987) as the primary source for this idea; Freedman applies Cover's idea to the formulation of a system of Jewish bioethics.

As Cover notes, "The principal word in Jewish law, which occupies a place equivalent in evocative force to the American legal system's 'rights,' is the word 'mitzvah,' which literally means 'commandment' but has a general meaning closer to 'incumbent obligation." (65) This subtle distinction is, in fact, the defining feature of the legal system identified by Batnitzky as a feature of premodern Judaism.

\footnotetext{
9 As Rabbi Yehudah Mirsky, an expert in Near Eastern and Judaic studies, points out in private correspondence, Bahya ben Joseph ibn Pakuda, in his publication Hobot ha-Lebabot, endeavored to emphasize what would be considered moral laws and ideas that are distinct from ritual practices [for a discussion of the question of halakhah and morality, see Englard (1988), Fishbane (1990), Lamm (2007, pp. 321-357), Lichtenstein (1975), Magid (2005), Sinclair (1992), and Statman (2010)].

${ }^{10}$ In the field of modern ethics, this attitude about halakhah and morality is characterized as deontological (see Solomon (1995, pp. 815, 816).
} 
Cover considers this difference to be fundamental to contemporary Jewish culture: "Indeed, to be one who acts out of obligation is the closest thing there is to a Jewish definition of completion as a person within the community" (67). The example he cites is that a bar mitzvah (literally, son of the commandment) is not "free" when reaching maturity; rather, as the term literally means, the boy is now obligated to perform the work commanded of him.

Broyde (2001) accepts Cover's distinction between rights and duties and explains that the main practical difference is that duties are the responsibilities of individuals to themselves and the community, while rights are what the community owes to the individual. He summarizes this difference, based in Jewish tradition, as "... the notion of a duty to act to help others, rather than the notion that one in need has a right to be helped" (xxiv). Broyde illustrates this distinction by citing a series of examples: In Judaism, he writes, “...there are no procreation rights, but rather a duty to procreate; there is no right due to mental incapacity, but rather a societal duty toward those who are incapacitated" (xxiii). A right can be waived by the individual more easily than a duty can be waived by the community; this is especially true in the case of those who are deemed to be suffering from medical incapacitation. In the absence of information concerning the individual's desire, the communal duty to protect the individual remains.

I would posit that the notion of duty leads to a legal model. Moreover, as we will see in the case of the conjoined twins, the parents of the twins were not consulting rabbis to discover the ethics of a given action, but rather to obtain guidance about what they were obligated to do under such medical circumstances. The work of Cover and Broyde on this subject is significant in that it identifies the continuing influence of the premodern legal character of Jewish medical thought in the practices of contemporary America. This legal character is evident in the report from the 1967 panel, and, as I will show in the discussion that follows, it manifests itself clearly in the 1977 case of the conjoined twins in Lakewood.

Another significant consequence of the legal nature of the Jewish process is the diversity of opinions that it engenders. As I will show with respect to the 1977 conjoined twins case and its aftermath, there is no single position on the legal or ethical dilemmas that emerge from such a complex medical case. The poskim, whom I will cite below (especially Orthodox rabbis Moshe Feinstein and J. David Bleich) employ a similar methodology in communicating with one another, drawing on extensive writings within the Jewish legal tradition dating back to the time of the Talmud. However, their usage of these sources and their application of their own logic often yield widely divergent results. The positions of other American Jewish denominations (including Reform, Conservative, and Reconstructionist) cannot be dealt with extensively in this paper, but Jack Segal's contribution to the 1967 report confirms that the legal nature of Judaism persists in some cases even outside of Orthodox circles. ${ }^{11}$

\footnotetext{
11 One prominent Conservative Jewish bioethicist is Dorff (1998). Teutsch (2005) discusses the use of legal constructs by a Reconstructionist bioethical authority. For an example of a Reform authority who uses a legal methodology, see the many articles on bioethics in the Central Conference of American Rabbis' CCAR Reform Responsa Collection at https://web.archive.org/web/20170824180649/http://ccarn et.org/rabbis-speak/reform-responsa/index/ (accessed August 22, 2018).
} 


\section{The 1977 Case of Conjoined Twins}

\section{Facts of the Case}

The birth of conjoined twins represents one of the rarest forms of births, occurring in roughly one out of every two hundred pregnancies involving identical twins. The incidence of the birth of conjoined twins, as compared with normal births, ranges from one in fifty thousand live births to one in one hundred thousand live births (Rees et al. 1993). In most cases, one of the conjoined twins is stronger than the other, and, without medical intervention, both twins may die. With surgery, it is possible in some cases to save the stronger twin while causing the death of the weaker one. Such an intervention raises considerable ethical and religious issues. Although such cases are relatively rare, advances in medical technology and surgical procedures have resulted in the reality that the dilemma about intervention in cases of conjoined twins arises more often than it might have in the past.

In September of 1977, a young and "deeply religious" Orthodox Jewish couple from Lakewood, New Jersey (as they are described in Drake 1977a), awaited the birth of a child. The mother gave birth on September 15 at Monmouth Medical Center in Long Branch, New Jersey (Shapiro 1977), to twin girls with a combined weight of $8 \mathrm{lb}, 10 \mathrm{oz}$. They were conjoined twins, and they were "immediately transported to the infant intensive care unit at Children's Hospital [of Philadelphia] to be treated for respiratory problems" (Shapiro 1977). The twins represented an anomaly: They were, in medical parlance, "thoracopagus twins", ${ }^{12}$ referred to in some of the literature quoted below as Siamese twins. Their distinctive physiology was extremely rare in that they shared one six-chambered heart. Soon after the twins' birth, Donald C. Drake, a medical reporter for the Philadelphia Inquirer, published a detailed article on the case that has been reprinted and cited many times:

Special X-ray studies the next day showed that the twin designated as Baby Girl B had an essentially normal, four-chamber heart that was fused to the stunted two-chamber heart of her sister, Baby Girl A.

The hearts were joined along the walls of the left ventricles, the main pumping chambers that push the blood through the body.

The connecting wall was only one-tenth of an inch thick - far too thin to be neatly divided in order to give each twin what belonged to her.

And even if this were possible, the stunted heart of Baby Girl A would not be able to support the child for long.

The doctors felt that they could not leave the babies the way they were either. They knew it would be only a matter of time before the overworked one and one-half hearts would start to fail, killing both babies. No twins joined at the heart like this had ever lived more than nine months" (Drake 1977a).

\footnotetext{
12 University of Maryland Medical Center (n.d.), "Facts about the Twins". http://umm.edu/programs/ conjoined-twins/facts-about-the-twins (Accessed August 2, 2016).
} 
When the parents learned that one twin (Baby Girl A) would have to die in order to save the life of the other baby (Baby Girl B), who had the normal heart, they believed that the ethical question "was much too difficult and important a question for the young rabbinical scholar [involved in the case], only in his early twenties, to try to answer on his own, so he consulted the rabbis in his community and the rabbis in his and his wife's families. Soon, Rabbi Moshe Feinstein, dean of [the Mesivtha] Tifereth Jerusalem seminary in New York City, was called in "to offer his rabbinic decision determining the correct course of action" (Drake 1977a).

Reports of the chronology of the decision-making process throughout the 1977 case situate the events in September and October of that year. Previous descriptions of the events have failed to note that the case took place during a significant time within the Jewish calendar, a time fraught with somber reflections on matters of life and death, referred to as the Yamim Noraim (Days of Awe) that begin with Rosh Hashanah (the start of the New Year) and end at the conclusion of Yom Kippur (the Day of Atonement). According to Drake (1977a) and others, the twins' father and rabbis met with C. Everett Koop, the pediatric surgeon, on September $20 .{ }^{13} 3$ days later, the rabbis met with him again, but this time without the parents. The twins had been born on the day after Rosh Hashanah according to the Jewish calendar, ${ }^{14}$ meaning that the first meeting (September 20) occurred on the day before the start of Yom Kippur, the most solemn day of the year. Thus, the meeting between the rabbis and the surgeon that took place without the parents occurred on the day after Yom Kippur (September 23). The period when the surgical team was waiting for the rabbis to make their decision was the biblical holiday of Sukkot, which began that year on the eve of September 26 and ended with the holiday of Simchat Torah on October 5 . The concurrence of the religious holidays in all likelihood played a role in the length and difficulty of the communications among the rabbis in New York and the doctors in Philadelphia. The rabbis returned with a decision the day after all the holidays had ended: October $6 .{ }^{15}$ Once the decision was made to permit the surgery to separate the twins, the team scheduled the procedure for October 11.

On October 10, Children's Hospital, with the future U.S. Senator Arlen Specter as its attorney, went to court to ask for a court order that would sanction Koop's method of surgery - that is, to sacrifice the debilitated twin in order to save the life her sister. As it happened, October 10 was Columbus Day, a secular holiday, when the court would usually be closed. Given the inability of the Jewish "court" to expedite its deliberations during the Jewish holidays, it is interesting to note that the

\footnotetext{
13 Dates in this paragraph are taken from Drake (1977a, b, 1978).

14 This day is called Tzom Gedalia, the Fast of Gedalia, a minor fast day that is alluded to in Zechariah $8: 19$.

15 Had the rabbis been convinced that a decision would fall under the legal rubric of saving a life, the "court" would have been able to override the travel and communications restrictions of the holiday and provide the hospital with a ruling. The fact that the rabbis did not do this indicates a number of things, including their professional obligations on the High Holy Days. I do want to tentatively suggest that many people involved in these cases, including the parents (as seen in a 2000 case of conjoined twins in the United Kingdom, as discussed below), seem to subconsciously hope that with slow enough deliberations, the case would resolve itself and nature would take its course.
} 
secular court met in a special session on a secular holiday to prepare a court order giving Koop the legal right to perform the surgery.

In a newspaper article the day after the surgery, the hospital staff offered an explanation to an interested public: "There had been only six known surgical separations of Siamese twins joined at the heart and ... only three of those were described in medical literature. Only one person has survived" (Shapiro). The surgery would be the third separation surgery Koop would perform at Children's Hospital; the first was in 1957, and the second in 1974, and both resulted in at least one surviving twin (Shapiro). While previous efforts at the separation of thoracopagus twins had failed, this time, Koop, a renowned and skilled surgeon who had performed separation surgeries in other cases of conjoined twins, would make the attempt. Still, none of those other cases had involved twins with a shared heart.

Following the surgery, Koop told a reporter that "...the surviving girl had only a 5 to $10 \%$ chance of staying alive after the separation. 'Right now,' he said, 'I feel very hopeful'" (Shapiro). While the surgical team considered the intricate surgery separating the hearts of the twins successful, other complications led to the death, 47 days later, of the surviving Baby Girl B. Drake of the Philadelphia Inquirer noted that once the weak twin had been sacrificed to save the twin with the stronger heart, "... it was not the abnormal heart that eventually killed Baby Girl B, but liver trouble and an infection that doctors could not stop" (Drake 1978). Specifically, Baby Girl B died as a result of contracting hepatitis B from a blood transfusion (Bleich 1996, p. 100). ${ }^{16}$

The details of this case from both a medical and an ethical perspective have been described in only a small number of articles and, thus, an accurate historical account of the events is not reliably available. ${ }^{17}$ However, the family insisted on complete anonymity and, to this day, their names have not been revealed.

\footnotetext{
16 An important aftermath of the story is that the family, which up to that point had been following the rulings of Rabbi Moshe Feinstein, rejected a ruling of Feinstein's spokesman, Rabbi Moshe Dovid Tendler, by refusing to allow an autopsy. As Donald C. Drake explains, "The parents, Orthodox Jews, refused to permit an autopsy. Rabbi M. D. Tendler, an authority on Jewish law, had advised the parents, who called him yesterday morning, that an autopsy would be permissible in such cases as this. In fact, he said, there was a religious obligation since such an autopsy would not be a 'fishing trip,' but something that might help prevent similar deaths in the future. But Baby Girl B's grandfather, himself a rabbi, felt differently, and the family declined" (Drake 1978). The question of autopsy is another important case for Jewish medical culture as it relates to the inviolability of the human body (called kavod ha-met in halakhic terminology). Considering the extreme rarity of thoracopagus conjoined twins, every autopsy would give information that would add to medical knowledge and potentially help to save other lives.

17 The most authoritative account appears to be from the sole contemporaneous reporter to focus on the matter of the conjoined twins, Donald C. Drake. Koop wrote his autobiography 13 years after the surgery - an autobiography that is brief in its description of the event. Furthermore, Koop's sole biographer, Gregg Easterbrook, does not seem to be wholly reliable in his account (see below). Drake is still alive, but he has not yet responded to my request for an interview.
} 


\section{The Religious Context}

Through happenstance, the 1977 case of the conjoined twins involved representatives of the three religions that Will Herberg focused on in his 1960 book Protestant, Catholic, Jew. These were also, as discussed above, the three religions represented by members of the 1967 panel. Koop was a devout Protestant; many of the nurses were Catholic; and the family members of the twins were Orthodox Jews. How the three groups conducted their ethical inquiries around the decision-making process followed a pattern that reflects each of these religions' medical culture. These cultures are reflected not in the conclusions reached by each group, but in the methods by which each group reached those conclusions. Each community had advocates who promoted inaction and those who called for the surgery-often for the same basic reasons - and yet the means for arriving at those decisions varied widely.

\section{The Jewish Family}

The young parents of the conjoined twins came from a "prestigious family of Torah educators" (Tendler 1996a, p. 126), and yet they did not rely on their family or their Lakewood community for assistance with the decision-making process. Instead, they sought out Rabbi Moshe Feinstein to review the details of their case and to render a decision regarding what they should tell the doctors: Should they do nothing, letting nature take its course, or should they agree to an operation that would almost certainly kill one child to save the other?

Rabbi Moshe Feinstein (1895-1986), who was born in Uzda, White Russia, immigrated to the United States in 1935. He was already, at the age of 40, recognized as a budding rabbinic leader among the Torah scholars in Europe. ${ }^{18}$ When he arrived in the United States, a large contingent of rabbis came to welcome him, including Rabbi Moshe Soloveitchik, the rabbinic head of the Rabbi Isaac Elchanan Theological Seminary of Yeshiva University. In the words of Rabbi Moshe Dovid Tendler, Feinstein "was the moral and halakhic conscience of the Torah community. Nowhere was his leadership more keenly felt than in the area of critical care medicine, where his empathy, sensitivity, and intellectual integrity were so widely recognized" (Tendler 1996b, p. vii). At the time of the 1977 case, Feinstein was a world-renowned posek, serving as an authoritative adjudicator of Jewish law for the world's Orthodox Jews.

Rabbi Moshe Dovid Tendler (1927-), who married Feinstein's daughter Shifra, is both a rabbi and a professor of biology at Yeshiva University, having received a doctorate in biology from Columbia University in 1957. Tendler, who is known for his expertise in medical ethics, has written and lectured widely on several controversial subjects, including end-of-life issues. He translated Feinstein's various medically oriented responsa into English, a translation that represents the only printed statement from Feinstein's "court" concerning his reasoning on the 1977 case of the

${ }^{18}$ I derived this information about Feinstein from Tendler's introduction to Feinstein's 1996 volume. 
conjoined twins. Tendler acted as a proxy for Feinstein, who did not travel to Philadelphia, during all of the discussions with Koop and the staff at Children's Hospital.

\section{Koop the Protestant}

C. Everett Koop's later fame as U.S. Surgeon General has retrospectively lent this case a measure of prominence. ${ }^{19}$ But more than his fame, Koop's identity as a Biblebelieving doctor - a key factor in his appointment to the position of surgeon general-is important to our understanding of this case as it relates to the medical culture of the different religions involved. Koop was a devout Presbyterian. He also had a relationship with religious Jews, as he described in his autobiography:

The operation was very tense... After producing the death of one twin it took me a little time to separate the body from that of the survivor. I then tenderly wrapped the body in a sheet and carried it to the door of the operating room, where I was told a rabbi would be waiting to take the body for burial. When I opened the door, I found an old friend. Rabbi Mandelbaum, whose presence somehow made me feel better about the whole affair. I had operated on many of his innumerable children (Koop 1990a, p. 113). ${ }^{20}$

Koop served as chief surgeon at Children's Hospital of Philadelphia from 1948 to 1981. According to his biographer, Gregg Easterbrook, “...he was celebrated within the medical community as the founder of modern pediatric surgery" (Easterbrook 1991). In Philadelphia, he was known not only as the doctor who saved many children whose cases were considered hopeless, but also — and most notably-for his work with the conjoined twins.

\footnotetext{
${ }^{19}$ See Anonymous (1957) [in addition to Koop's eponymous autobiography] for background on Koop and the surgical recognition he earned through his earliest cases. See Anonymous 1974 for a discussion of Koop's most celebrated case before the 1977 case of the Lakewood twins-the separation of the conjoined twins Clara and Altagracia Rodriguez, who were born in 1973 in the Dominican Republic, which will be discussed further below.

${ }^{20}$ I have not been able to identify this Rabbi Mandelbaum, nor is there any record of Koop asking him for specific Jewish insight into medical ethics, or even for how to deal with the family and their rabbis. Many years later, in 2012, Koop still recalled his encounter with Mandelbaum and its profound effect on him, as described below. Drake, the medical reporter on the story, had turned his account of the story of the 1977 conjoined twins into a play titled "Choice". When "Choice" premiered at Philadelphia's Painted Bride Art Center in 2012, longtime Philadelphia Inquirer reporter Dotty Brown interviewed the 96-year-old Koop, who was then wheelchair-bound. "The reading brought back to mind his own 'religious' moment during the surgery", Brown wrote in her article, "C. Everett Koop and a Choice Between Lives", which was later published in the Jewish Daily Forward. "He explained that at the children's hospital he had been caring for the children of a rabbi, and talked to the rabbi about the twins. Still, Koop had not planned on what to do with the body of the baby destined to die during surgery. 'When I tied off one carotid artery and killed a child', Koop said, 'I'd given no thought about what would happen to the body... I had one dead baby and one live baby; I separated them. One of the nurses took the child who was now dead and carried it to the door of the operating room. The door opened and there stood the rabbi.... The fact that he was there seemed almost like God's blessing on what I had just done" (Brown 2012). It should be noted that Koop's memory of who carried the deceased baby to the door, as stated in this document, differs from the recollection that he offered in his autobiography.
} 
In his autobiography, Koop notes, "My colleagues and I operated on over ten pairs of Siamese twins while I was at Children's Hospital, but three pairs became well known" (Koop 1990a, p. 144). Koop's first case of conjoined twins, in 1957, involved Patricia and Pamela Schatz, who were joined at the base of their spines. Koop successfully separated the twins, and, although Pamela later died at the age of 9 from a congenital heart defect, the surviving twin, Patricia, lived on to marry, and she invited Koop to her wedding (Koop 1990a, p. 144). ${ }^{21}$ Koop urged the parents to treat the twins like normal children. "Now, don't treat those girls like hot-house children", he reportedly told the parents. "They're just as healthy as the average girls their age" (Lowry 1957).

Koop's fame as a pediatric surgeon who specialized in separating conjoined twins grew after his successful separation of conjoined twins born to Salvador and Farida Rodríguez of the Dominican Republic in 1974. In recollecting the surgery 8 years later, he wrote, "I began the day with prayer, I also read the Bible. A verse in Psalms which said the Lord will support the righteous became my help in time of need" (Nason 1982, p. 16). Both twins, Clara and Altagracia Rodriguez, survived the surgery. Despite his affiliation as a Presbyterian, Koop went to the Dominican Republic to preach in the family's Roman Catholic Church "in a service of Thanksgiving... after the separation and again on the first anniversary" (Nason 1982, p. 16). Tragedy struck 2 years later, however, when Alta, one of the twins he had saved, died in an accident by swallowing a bean that became lodged in her throat. Koop traveled again to the Dominican Republic to speak at her funeral. In commenting on his motivation, he said, "It was only fitting that I go down at the time of sadness and remind the townspeople that God is sovereign in all things, that we had thanked Him for the separation, and now we should thank Him for taking Alta home to Himself' (Nason 1982, p. 16).

In a People ${ }^{\circledR}$ Magazine article describing the event, the terms used for a general readership reveal the common attitude regarding such anomalies: When the Rodríguez twins were born, the article announced, they were "doomed to spend life sharing the same grotesque body-if, indeed, they would live at all". The article declared that Koop's 10-hour surgery separating the twins, who were born joined at the waist and pelvis, "...made each little girl a reasonably normal human being". After the surgery, Salvador Rodriguez reportedly called Koop and his fellow physicians "gods", but Koop described himself as "a pretty deeply committed Christian, a Bible-believing conservative evangelical” (Anonymous 1974, p. 19).

In Donald C. Drake's description of Koop, the medical reporter includes the crucial information that the surgeon was a Presbyterian, and, like the parents of the 1977 twins, "a deeply religious man" and one "who has frequently spoken out nationally about the sanctity of human life" (Drake 1977a). Easterbrook's description resonates with Drake's; in Easterbrook's portrayal, Koop was deeply committed to a religious world view:

\footnotetext{
21 In a strange coincidence, these conjoined twins, Pamela and Patricia Schatz, were born on September 27, 1957, which was the second day of Rosh Hashanah on the Jewish calendar for the year 5718, and Koop separated them on October 5, 1957, which was the eve before Yom Kippur.
} 
Generally, Koop paused to pray before beginning an operation, though he says he did this not in the sense of asking for some dusting of magic but to help concentrate his thoughts on the task ahead and what really matters in life. But in events like the death of a child, the world of faith takes on additional meaning. In Protestant doctrine, one who has tried to live a moral life and has accepted Christ not only goes to heaven, but is in every way better off than when on earth. So there is no cause to mourn his fate. Several Christian interpretations say that the real victim in the untimely death of a righteous person is not the deceased, but the surviving family and friends, who must go forward with a ray of light removed from their lives. Even if the loss is difficult, however, this view teaches that Christians must accept it as a manifestation of God's divine plan" (Easterbrook 1991, pp. 19-20).

Koop has been quoted as testifying about his religious beliefs: As reporter Arthur J. Snider wrote in the Chicago Daily News, "[Koop] attributes his self-possession to 18 more years of experience plus what he calls 'my anchor-a complete belief in the sovereignty of God. 'Having that, knowing that someone else is running the show,' he says, 'gives me a tremendous amount of comfort'” (Snider 1974).

Koop has also suggested that his religious outlook defined his work as a surgeon. He told Drake that he regarded the human body with awe, and that he felt the sanctity of human life (Drake 1977a). He indicated that, for him, performing surgery was the ultimate expression of his sense of awe. In his autobiography, he wrote, "I love surgery because I have always had an abiding reverence for the human body, reverence for the ways its anatomical details allow it to function... reverence for the tissues themselves, especially the delicate ones of infants" (Koop 1990a, p. 99). This outlook, combined with his compassion and his desire to help children, led him to champion the field of pediatric surgery, significantly improving survival rates and developing numerous surgical techniques. His fame in later years was directly tied to the advances he had made in the field of pediatric surgery and to his opposition to abortion and the mistreatment of children.

It was this public advocacy that attracted the Reagan administration to appoint Koop as surgeon general. In that role, Koop advocated strongly for the protection of the lives of children. He especially advocated for those with severe disabilities, as seen in the "Baby Doe" case-a case involving a severely handicapped infant born in 1982 who perished after being denied medical care that would have allowed the child to survive. "Having devoted my career to saving the lives of hundreds of such infants", Koop wrote in his autobiography, "I could not remain detached" (Koop 1990a, p. 240). ${ }^{22}$ Koop used his role as surgeon general to lobby Congress to create legal protections for such children. In 1984, Congress passed the Baby Doe Law, an amendment to the Child Abuse Prevention and Treatment Act of 1984, rendering the withholding of life-saving treatment and nutrition from any impaired infant

${ }^{22}$ See also Koop (1990b) for a specific essay he wrote about end-of-life issues. 
punishable as child abuse. ${ }^{23}$ One would guess that Koop's devotion to handicapped children, as seen in the case of Baby Doe, would have led him to believe that passively standing by while a child died was a form of infanticide.

A vital point about Koop's religious attitude toward medicine is that he saw complex cases as opportunities to help heal others, given his ability and knowledge. In cases like that of Babe Doe, and in instances where others might see the birth of conjoined twins as a sign that the babies were meant to die, ${ }^{24}$ Koop felt that he had a divine mandate to help and to heal based on his knowledge and skill. He saw his work as helping to perfect nature. As he wrote in his autobiography, "I loved the technical challenge of surgery when it could repair what nature had failed to complete" (Koop 1990a, p. 101). For Koop, knowledge could turn a crisis into a possibility for healing. His knowledge of medicine and pediatric surgery led him to strive to save lives and not to condemn patients to death through neglect or inaction. For example, in the case of the Rodríguez twins, Koop wrote, "The parents didn't want the operation if it meant that one of the girls had to die so that the other could live". Koop reassured the parents, as recalled by the translator in the case, a Mrs. Zimnoch, and they agreed to move ahead with the surgery.

Koop and his family were active in their church. This became crucial when his own college-age son, David, died in a freak mountain-climbing accident. Koop's good friend Dr. Patrick Pasquariello, a pediatrician at Children's Hospital, spoke to Easterbrook about the effect of the loss on Koop's life. "After his son's death", Pasquariello said, "religion may have become even more important in the life of this already religious man" (Easterbrook 1991, p. 18). Easterbrook supports this claim, noting, "Koop's family had long been churchgoers, active in the Evangelical Presbyterian denomination; the Bible in David's dorm room was open on his desk the day he died" (18-19). Koop did not talk about this link to David in his own writings. Indeed, as noted above, Protestant doctrine would have mandated an acceptance of David's death as a result of divine will. But this acceptance of death after the fact did not mean that Koop was willing to let death take its natural course when he could intervene medically to prevent it.

In the 1977 case of the conjoined twins born to Orthodox Jewish parents in Lakewood, New Jersey, Koop, because of his moral and religious philosophy, was particularly sensitive to the parents' need to await a rabbinic decision before they would agree on the medical path to follow for their children. In his autobiography, written years later, Koop summarized his reasoning for his decision to do the surgery:

\footnotetext{
23 See Koop chapter 10, 240-261, as well as the section on Koop's papers in the U.S. National Library of Medicine of the National Institutes of Health: http://profiles.nlm.nih.gov/QQ/Views/Exhibit/narrative/ babydoe.html.

24 The notion of being "meant to die" can emerge from either a secular or a religious perspective. Many secular ethicists responded to cases of conjoined twins-e.g., the 1993 case of Amy and Angela Lakeberg in Chicago_-with appeals to institute protocols of medical futility (see Brandon 1994; Dougherty 1993; Thomasma et al. 1996). From a religious perspective, those who advocated a perspective of medical naturalism were expressing a tacit acceptance of the idea of medical futility (Zohar 1997).
} 
The twins had one six-chambered heart, which was failing because it could not support the life of the two growing children. In order for one twin to survive, the other would have to be sacrificed. This was an extraordinarily unusual and difficult situation. Religious issues made it even more difficult. Both of the grandfathers were Hasidic rabbis, and they insisted on a seven-day Talmudic argument on the ethical issues involved. I was just as concerned, but I wasn't sure the children would survive the long argument. Eventually we all came to the same position: One twin, the smaller, was essentially a parasite on the other. It was clear we had no choice about which twin would have to be sacrificed (Koop 1990a, p. 112).

In the end, both Koop and the Orthodox Jewish parents of the twins reached the same conclusion-namely, that the surgery should proceed despite the certainty that one of the twins would die. However, the distinctiveness of the Jewish approach to medicine lies in the process: Whereas Koop meditated on the problem in a spiritual, solitary manner, the Orthodox Jewish parents of the twins engaged in a lengthy legal process - a thumbprint of premodern Judaism.

\section{The Catholic Nurses}

As described above, the family of the conjoined twins and their chief surgeon were both animated by religious concerns about proper medical treatment. Drake's account added a third group with such concerns: Many of the nurses at the hospital, mostly Catholic women, voiced their unease about the proposed treatment, especially as it would lead to the active killing of an infant. They reportedly believed that Catholicism affirmed the inviolate sanctity of each life without regard to quality-oflife issues. Drake summarized the perspective of the nursing staff with respect to the case:

Word spread through Children's Hospital that surgeons were planning to sacrifice one of the Siamese twins. ...

Mrs. Jane Barnsteiner, who is Catholic and the associate director for clinical nursing, was asked about the twins by head nurses as she went about the hospital each day on her rounds.

The Catholic nurses, of whom there are many, were particularly concerned that the surgeons might be doing something that violated the teachings of their church.

The word "sacrifice" was used so much by the nurses in discussing the matter that Mrs. Barnsteiner herself became concerned and decided to consult a priest.

At the same time, the nurses in the operating room were becoming particularly uneasy because they knew that they would be called upon to participate in the surgery if it took place. ...

Miss Betsch [, assistant director of the operating room complex,] said that she would consult a priest. A Catholic herself, she would not want to participate in the surgery if it went against her church" (Drake 1977a). 
Complicating these concerns was the knowledge by the nursing staff of Koop's pro-life advocacy: "[The] Roman Catholic nurses [were] aware of Koop's pro-life's stance", and so his "decision [to perform the surgery] shocked his hospital staff" (Kattner 1985, p. 1).

The word "sacrifice" was of particular concern to the Catholic nurses. At the time, Koop did not seem to believe that his decision to proceed to surgery would involve sacrifice. In author Joseph F. Kattner's report, the nurses "at first refused to help him kill one of the babies. Koop said that he told the nurses, 'I can watch two babies die slowly or one die swiftly"' (Kattner 1985, p. 1). It appears from Koop's comments that his concern was not that he would "sacrifice" one child for another, but that the separation should be done humanely, resulting in the swift death of one child and the only possibility of saving the life of the other. ${ }^{25}$

Meehan (1978), an associate professor of moral theology at Saint Charles Borromeo Seminary in Philadelphia, acted as a consultant to the Catholic nurses in the case. In his 1978 account of the case, he wrote this: "A few days before the operation I was called into consultation by a priest, who himself had been contacted by some nurses. These were Catholic nurses, who were scheduled to assist at the operation and who were puzzled about the problem of the operation ending in the death of one of the twins" (Meehan 157). Ultimately, Meehan advised the nurses that it would be permissible to assist at the surgery, despite their opposition on the grounds summarized in the 1967 report, because of the doctrine of the "double-effect" principle. "According to a common articulation of the principle", he wrote, "any action having two effects-one good and one bad-is permissible, if (1) the good effect does not come by means of the bad effect, and (2) there is a proportionate reason for permitting the bad effect". Like the Catholic authorities in the 1967 report, Meehan does not cite a source in canon law for this concept; however, he does refer to the reasoning of the Jewish theologians in the case. ${ }^{26}$ Most important in explaining his position, Meehan refers to an analogy. "The analogy used by the Rabbis considering the case and also used to obtain the court order was, I believe, basically a sound one, illustrating the point quite well". He then goes on to present the analogy of

\footnotetext{
25 Nevertheless, the word "sacrifice", which had caused the nurses so much distress, later appeared in Koop's autobiography: "In order for one twin to survive, the other would have to be sacrificed" (Koop 1990a, p. 112). However, Howard S. Shapiro, a Philadelphia Inquirer staff writer who presumably attended the press conference on October 11 following the surgery, did not use the term "sacrifice". Rather, he employed a more clinical wording, writing that Baby Girl B was "separated" from her sister and that "the other girl died". (Shapiro 1977, 1A) On November 20, 1977, reporter Donald C. Drake followed up with an article on the condition of the surviving twin, who at that point was suffering from many postoperative ailments; he was the first to use the term "sacrifice" relating to Baby Girl A in the Philadelphia Inquirer (Drake 1977a, b, 14A). In a January 12 article, Drake reported on the death of Baby Girl B and used the phrase "purposely let die" regarding the death of Baby Girl A. (Drake 1978, 1A). The initial operation to separate the twins was performed on October 11, 1977 and Baby Girl B survived until January 11, 1978.

26 The absence of references to canon law in Meehan's discussion is noteworthy, as it represents a departure from a legal methodology with a long history in Catholicism. For an example of a more legalistic approach to medical issues in Catholicism, see the report of Michael Moodie et al. on a 1993 symposium on religious law. When asked to deal with religious law, the Catholic contributors to the symposium adopted that rhetorical strategy.
} 
two mountain climbers joined by a rope. One mountain climber has fallen and is dangling by the rope. The other mountain climber's life is endangered by the weight of his vulnerable friend. Each will soon fall to his death. In this circumstance, the viable climber is permitted to cut the rope- "an action of separation that is aimed at protecting the only life that can be protected". (158-159).

In his article, Meehan stresses the Catholic medical-ethical position that the death of Baby Girl A would be a morally indirect effect of the surgery: "It is an inevitable side effect and therefore not a bad means to a good end.... Rather the moral indirectness of Baby A's death is reflected in the physical realities of the case, namely, the impossibility of saving both children... [and] the fact that, if nothing is done, both will die. These realities give flesh to the concept of moral indirectness. They are such as to allow that the death of Baby A is unintended and that it is therefore not a morally evil means, but rather a premoral physical incidental misfortune" (163-164). This reasoning is especially significant because it conflicts with the Catholic position in the 1967 report and, also, as we shall see, with the position of the Catholic authorities involved in the 2000 conjoined twins case in the United Kingdom. Furthermore, Meehan's article is a very tightly argued legal/philosophical piece, which the author even describes as "Catholic casuistry" (160), yet the article includes no references to legal works. Rather, as stated, Meehan suggests that he was influenced in his thinking about the surgery by the analogy the rabbis used in their legal argument.

In 2000, a case of conjoined twins arose in the United Kingdom, and the Catholic authorities reverted to their 1967 position. A Catholic couple living in Malta, Michelangelo and Rina Attard, became the parents of conjoined twins, referred to as Jodie and Mary. Their parents brought the children to England to be examined. ${ }^{27}$ This case diverges from the 1977 case most pointedly because of the dissimilarities between the legal systems in the United States and the United Kingdom. However, it is similar to the 1977 case in Lakewood in two respects: First, the medical consensus was that one twin would have to be "sacrificed" (see footnote 25 above) so that the other twin could live. Second, like the parents in the 1977 Lakewood case, the Attards were attempting to follow their religious beliefs in arriving at a decision about surgery to separate their conjoined twins. Their interpretation of their Catholic tenets led them to refuse to permit the operation to be performed, and to let "God decide" (Anonymous 2000). The apprehensions of the Catholic nurses in the 1977 case may be readily understood in light of the 2000 case. In the 2000 case, however, the state intervened to force the operation to save the stronger twin, Josie, whose real name was later revealed to be Gracie Attard. She was still alive as of 2015.

In the 2000 case, the Catholic British clergy [including the Archbishop of Westminster, as cited in Phang (2001b, p. 108)] ruled against separating the twins, and

\footnotetext{
27 For the primary source facts about this case, see decisions of the Court of Appeal of the Senior Courts of England and Wales (Civil Division) in Anonymous (2000), and Anonymous (2002). For perspectives on this case by legal scholars, see Anonymous (2002), Davis (2011), Freeman (2001), Hewson (2001), McEwan (2001), Sheldon and Wilkinson (2001), Uniacke (2001), and Watt (2001, 2012). For commentary by bioethicists, see Cowley (2003), Harris (2001), and Paris and Elias-Jones (2001). For the view of Roman Catholic experts, see Latkovic (2001), and Phang (2001a, b).
} 
in doing so, they rejected the arguments of Meehan. They explicitly abandoned the double-effect principle (Watt 2012; Wenkel 2006). In his 2001 article on these conjoined twins, Andrew Phang suggests that other Catholic authorities might have ruled in favor of separating the twins. For example, he cites the statement of French-American philosopher Germain Grisez (Phang, 108-109), whose reasoning followed that of Meehan: "Therefore, in my judgment, if one baby certainly or probably will not survive the surgery, the attempt will be unfair to that one unless two conditions are met: (1) without the surgery, the abnormality of the babies' shared $\operatorname{organ}(\mathrm{s})$ is likely to result soon in the death of both, and (2) with the surgery, the prospective survivor's prospects are greatly improved" (Phang 2001b, p. 109, fn. 260).

\section{The Involvement of the State}

In the 1977 case of the Lakewood conjoined twins, the decision on the part of Children's Hospital in Philadelphia to seek legal protection in advance of the surgery, as described by Drake, seems to have been motivated by a quirk in Pennsylvania law that would allow prosecution to be brought by anyone-even a person with no direct ties to the case. ${ }^{28}$ Koop's autobiography notes that his motivation emerged from a specific political concern: "Meanwhile, a friend warned me that my pro-life position had made me some enemies, and I might be taken to court in a civil suit in Pennsylvania if I deliberately brought about the end of the life of one twin. I therefore demanded a court order to do the separation" (113).

As a result of Koop's pursuit of legal protection from the government, documents exist that attest to the similarities between the Jewish authorities' argumentation and the legal argumentation of the secular court. In particular, the analogies they use are strikingly similar ${ }^{29}$ :

The lawyers then went to their second line of reasoning and judicial precedent, which said that what might appear to be a crime is not a crime if a court rules that the good outweighs the bad and accordingly hands down a court order. Because there is greater good served by saving one child instead of losing both of them, the court would be justified in issuing such an order, the lawyers insisted" (Drake 1977a, b).

As shown in this excerpt, the law of "justification of necessity" protected Koop in this case - a law later used by the British Court of Appeal in the 2000 conjoined twins case, as I will show below. The law stipulates that an action that may seem

\footnotetext{
${ }^{28}$ I have not been able to find any vestige of the court record of these deliberations. Davis (2011, p. 432 , f13) confirms that "there is apparently no written record of the hearing or decision". It is noteworthy that when the British Court of Appeal in 2000 cited the 1977 case, the judges, too, did not use the court records; rather, they depended on secondary accounts about the case, specifically from Annas (1987). See Ward and Robert Walker (2000).

29 The similarity between the analogies is such that some later articles that reference the 1977 case conflate the arguments of the two "courts"- that is, the secular court and the Jewish "court" (Thomasma et al. 1996, p. 6).
} 
like a crime can be justifiable because of the greater good. ${ }^{30}$ One of the precedents cited by the hospital's lawyers in the 1977 case dealt with a fire on a boat: Most of the sailors were unable to escape because the porthole leading to safety was being blocked by a panicked sailor who could not or would not move. The other sailors threw him aside to his death so that they could escape. In that case, the sailors' action was deemed to be justified because it saved so many lives.

Coincidentally, at the very same time, another American case of conjoined twins involved the pursuit of legal protection for the surgery that would separate the twins. As detailed in an article in the Journal of Pediatric Surgery on September 14, 1977, conjoined twin girls were born in Arkansas - a day before the birth of the Lakewood, New Jersey twins. These twins were described as "dicephalus dipus tribrachius"-a malformed baby with two heads, two lower limbs and three upper limbs. Unlike the New Jersey twins, each of the conjoined twin girls had a heart. In reference to the Arkansas case, Golladay and his colleagues (1982) describe the assessment of the need to separate the twins, as well as the need to secure legal protection:

During analysis, it became increasingly apparent that the twins could not be successfully separated with survival of both. After considerable discussion with the parents, with the [Arkansas] State Attorney General, and the County Prosecuting Attorney, a decision was reached. The parents desired separation. The Prosecuting Attorney, with the Attorney General concurring, concluded that surgical separation of the twins was protected by the law of justification in the constitutional right of privacy and that no criminal prosecution would result from the demise of the right twin as a result of the surgical separation" (Golladay et al., p. 259).

While in both cases the parents agreed to the separation of the twins, the Philadelphia case is noteworthy for this discussion in that the parents required religious guidance to come to that decision.

\footnotetext{
${ }^{30}$ It is important to understand the meaning of "justification" in legal terms: "Justification is a reason for committing an act which otherwise would constitute an actionable wrong or tort. It is an ancient principle of the common law that a trespass may be justified in many cases" (http://definitions.uslegal.com/j/ justification/). "Necessity" is a related concept: "Usually, defendants argue that their actions were necessary to prevent a greater evil. A person can use physical force upon another person when s/he reasonably believes that it is necessary to defend himself/herself or a third person.....Necessity amounts to a defense of justification in most states" (https://definitions.uslegal.com/n/necessity/). See Summers (1978) for more about the linkage between justification and necessity.
} 
It is significant that, in the Arkansas case, the attorney and the attorney general (future U.S. president William Jefferson Clinton ${ }^{31}$ ) connected the issue of justification to the right of privacy. Golladay and his colleagues described the right of privacy as one of the principles that had been established in the 1976 case of Karen Ann Quinlan, a New Jersey woman who was placed on a feeding tube and ventilator after suffering irreversible brain damage and lapsing into a persistent vegetative state. Her family sued, demanding that the treating hospital, St. Claire's Hospital in Denville, New Jersey, remove Quinlan from the ventilator; the New Jersey Supreme Court determined that the right of privacy encompassed a family's right to determine its member's medical fate. The Constitutional right to privacy had been most fully established in the 1973 case of Roe v. Wadea case that affirmed the legality of a woman's right to have an abortion under the Fourteenth Amendment to the U.S. Constitution-although this right remains controversial (Supreme Court of the United States 1973). The court case of the Arkansas conjoined twins was occurring simultaneously with the court case in Philadelphia and, in both, the principal actors were seeking legal protection for the medical staff and the family as they decided to proceed to surgery.

However, in the Arkansas court case, as described by Golladay and his colleagues in the Journal of Pediatric Surgery, the need was for legal clarity, since the case was not weighed down by the political overtones related to the pro-life views of Koop, which were rooted in his religion. Ultimately, the Arkansas lawyers referred to principles similar to those that were being used in Pennsylvania.

\section{The Jewish Process}

In his article about resolving the ethical issues surrounding the problem of conjoined twins, Andrew Phang (2001b) notes that the Jewish argument "may be consistent with Koop's own reasons", but that Koop had arrived at his personal conclusion through a very different process from the one used by the Orthodox Jewish family and its poskim (rabbinic legal authorities). As Phang writes, "It is clear that this was not the focus of his own process of reasoning, save, perhaps, by way of confirmation of what he felt was God's will in the matter" (108). Phang believes that Koop operated according to Christian principles in decision making, specifically, the requisite

\footnotetext{
31 The account in Clinton's (2004) autobiography reads as follows: “Another really interesting problem I faced as attorney general was literally a matter of life and death. One day I got a call from the Arkansas Children's Hospital. It had just recruited a gifted young surgeon who was being asked to operate on Siamese twins who were joined at the chest, using the same systems to breathe and pump blood. The systems couldn't support them both much longer, and without surgery to separate them, they both would die. The problem was that the surgery would certainly kill one of them. The hospital wanted an opinion saying that the doctor couldn't be prosecuted for manslaughter for killing the twin who wouldn't survive the surgery. Strictly speaking, I couldn't guarantee him that, because an attorney general's opinion protects the person receiving it from civil suits but not from criminal prosecution. Nevertheless, the opinion would be a powerful deterrent to an overzealous prosecutor. I gave him an official letter stating my opinion that the certain death of one of the twins to save the life of the other would not be a crime. The doctor performed the operation. One twin died. But the other one lived" (Clinton, 373-374).
} 
guidance by the Holy Spirit is the key (108, emphasis in original). Herein lies the most significant difference between Koop's process of determination and that of the Jewish poskim. While Koop was guided by faith, the twins' parents and their posek, Rabbi Moshe Feinstein, followed a legal process. In this, as I will suggest below, he was adhering to an understanding of Judaism that encompassed not only spiritual aspects, but also legal and ethical aspects.

In his account of the case, as related by his father-in-law, Rabbi Moshe Feinstein, Rabbi Moshe Dovid Tendler relates that he met with Koop to ascertain the pertinent medical facts:

On September 20, I met with Dr. Koop and his staff to determine the medical facts. The first halachic concern was to establish that we were, in fact, dealing with two separate human beings. Although they were joined at the chest and their livers were co-joined, as were the hearts, the girls were separate human beings with their own brains and nervous systems. Dr. Koop recommended that the twins should be separated as soon as possible, because there were signs that the heart was failing and could not maintain the load of supplying blood to two infants. It was emphasized that even with surgery the chance was slim that one could be saved. Never before had Siamese twins been successfully separated from a ventral connection, and certainly not when they had a joined liver and a single heart between them (Tendler 1996a, pp. 126-127).

For halakhic reasoning, it was important to know that the conjoined twins were two separate human beings. Koop and his team did keep the rabbis informed as to changes in the medical condition of the twins. At one point, on October 3, (which was an intermediate day of Sukkot), Feinstein was told that there had been changes in the heart rate and respiration of the twins (Drake 1977a). Feinstein then asked Koop (through Tendler) another key medical question: "Was Dr. Koop sure that the six-chambered heart could only be given to Baby B? Could it not also be given to Baby A and have Baby B die? Dr. Koop responded that there was no doubt that the only infant who could be helped by surgery was Baby B, because in addition to the shared liver and heart, Baby A also had a circulatory defect that would not permit her to survive any length of time, even if she were given the six-chambered heart" (Tendler 1996a, p. 127).

On the basis of these and other pertinent data, Feinstein was able to make his deliberations and render a decision. He did not write his reasoning down at the time, but Tendler recreated it from memory for publication in Feinstein's medical writings (Tendler 1996a). All the subsequent commentaries rely on Tendler's rendering of the story as well as the articles by Drake. Tendler offered this recounting:

Rav Feinstein compared the case of the Siamese twins to this classic case of the conflict for survival between a mother in childbirth and the fetus. Baby A had no independent ability to survive. Her entire survival was completely dependent on her sister, who had the circulatory system to back up the functioning of the heart and liver. To Rav Feinstein's critical question, "Can the heart be given to Baby A and she would live?" Dr. Koop had responded, "No, there is no way to save Baby A. The issue is only should both die or should 
Baby B be saved." Without the attempted separation, both would surely die, and therefore in halakhic terminology we classify the baby that had no independent survival, Baby A, as the pursuer, as if she were pursuing her sister and threatening her life (Tendler 1996a, pp. 129-130).

Tendler also added that this line of reasoning, the analogy to a mother in a difficult childbirth, was Feinstein's perspective, but said that "an objection was raised" (Tendler 1996a, p. 130). Tendler then devoted the rest of the chapter to an elaboration of what he called a "second approach that leads to the same conclusion, but based upon a different halachic principle" (Tendler 1996a, p. 128). He recorded it "since it was presented in great detail during the discussions that led to the final permissive ruling". In a close reading of this comment, we should note that Tendler introduced himself into the discussion, obscuring Feinstein's reasoning somewhat. Tendler reported in the passive voice that a "second approach" had been proposed, without identifying the originator of this other line of reasoning, which Feinstein ultimately rejected.

According to the Mishnah, it is forbidden to give one life for another. The only exception is for a mother delivering a baby (Mishnah Ohaloth 7:6). According to that passage, one may sacrifice the fetus if it is still fully enclosed within the mother's womb. However, once the head of the baby emerges, it is considered to be alive, and neither life may take precedence over the other. This commentary is expanded in the Babylonian Talmud Tractate Sanhedrin (72b), which asks whether the baby is considered a rodef - a pursuer. The answer given in the Talmud is that the pursuer is not the baby, but Heaven itself, and since it is not the baby who is attempting to destroy the mother's life, the baby cannot be sacrificed to save the mother's life.

According to Tendler, Feinstein reasoned that the mother's life takes precedence when the fetus is dependent on the mother for life. Hence, once the head emerges, the fetus becomes a baby - a baby who can live even if the mother is dead. In the case of the conjoined twins, Baby B was analogous to the mother as described in the Mishnah. Baby A was analogous to the fetus in the sense that she was completely dependent on the life of Baby B. This can be clearly seen from the fact that Baby B was able to survive without Baby A. By contrast, there was no chance that Baby A could have survived if Baby B had died. Koop confirmed, once the surgery started, that Baby A would not have been able to survive independently.

The reasoning laid out in the Mishnah Ohaloth cited above provides an explanation for the questions that Feinstein is reported to have asked (Drake 1977a). In asking whether the six-chambered heart could have been given to Baby A instead of Baby B, he was asking whether Baby A was truly dependent on Baby B for life. Drake gave this response:

Dr. Koop could not understand why he was being asked such a question, but he told them no. The circulatory system was set up in such a way that the transfer could be made only to Baby B.

Then Rabbi Tendler asked whether Dr. Koop was certain that Baby Girl B would also die, even with the surgery.

Dr. Koop said that Baby B probably would die regardless of what was done, but that it was not a certainty (Drake 1977a). 
In Tendler's narrative, significantly, it was only after Feinstein received the answers to these questions that he gave his decision that surgery was permitted:

Further, sophisticated testing had determined that the halakhic concept of dependency was, indeed, the relationship between the twins. The two-chambered heart, which was the heart of Baby A, was receiving its blood though two apertures leaking from the four-chambered heart. Except for that contribution of blood to the two chambers Baby A would have died in utero. This was the analysis that allowed the surgery to proceed (Tendler 1996a, p. 130).

Based on the knowledge that one life was dependent on the other, Feinstein reached the conclusion that the viable life must take precedence. Since Feinstein's opinion was not written in the form of a responsum, the path of his reasoning can only be guessed at. One wonders why he did he not write it down. Perhaps he considered the issue so specific that it merited the level of a p'sak, and did not fall into the category of a responsum, a genre of writing from which one may derive generalizations applicable to analogous cases (Breitowitz 1996). ${ }^{32}$

Nevertheless, one prominent rabbinic scholar, J. David Bleich, a professor of Talmud and an authority on Jewish law, ethics, and bioethics at Yeshiva University's Rabbi Isaac Elchanan Theological Seminary, did attempt to elucidate Feinstein's reasoning and then offer his commentaries on the decision-commentaries that reveal his hostility to Feinstein's decision. ${ }^{33}$ In a 1996 article in the series "Survey of Recent Halakhic Periodical Literature", in the journal Tradition: A Journal of Orthodox Jewish Thought, Bleich was prompted to write about the topic of conjoined twins because of the focus on the recent case of the conjoined twins Abby and Brittany Hensel, who were born in Minnesota on March 7, 1990. These twins were born with conjoined bodies but separate heads and necks, and several of their vital organs were doubled. They did not undergo medical separation, and as of this writing, they are alive and healthy. Stories about the Hensel twins had appeared in Time and Life magazines at the time that Bleich was writing his article. In his characteristically thorough manner, Bleich covered in detail the science and history of conjoined twins as well as the place of conjoined twins in halakhic literature. He devoted a major section of his essay to the 1977 case of the Lakewood conjoined twins, which he entitled "The Philadelphia case of 1977" (Bleich 1996). Bleich offered his understanding of Feinstein's reasoning in this case based on his knowledge of Feinstein's other responsa and also based on "various accounts of his decision" already published (100). Bleich provided other responses from Feinstein dealing with the issue of "giving one life for another", and he used those other statements to explain the consistency of Feinstein's views. As Rabbi Yitzchok A. Breitowitz has noted, Feinstein's philosophy of p'sak does request that rabbis who read his decision should look into the original sources and, in this way, Bleich was following the process

\footnotetext{
32 See also Glick (2012). I send thanks to Yehudah Mirsky for this source.

33 The intensity of the debate between Feinstein and Bleich in this case pales in comparison to the intensity of their debate over brain stem death [for more information on this topic, see the discussion and citations in Cypess (2015, pp. 66-89)].
} 
that Feinstein had mandated (Breitowitz 1996) (it should be noted that Tendler also attempted this reconstruction). In surveying the various sources that Feinstein is said to have used, Bleich provided his own assessment of the applicability of the sources and his criticisms of their relevance. For example, he did so with regard to a story of two men who jump from a burning airplane: One of the men is designated a rodef (pursuer) if, "through his actions [he] will bring about the death of the first" (101).

Bleich then offers a third section of his essay — an "objection to Rabbi Feinstein's ruling" by another rabbinic scholar (103). Bleich appeared to sympathize with the critics; he even questioned Koop's medical reasoning. This critical stance is further developed in letters to the 1997 issue of Tradition (Low and Bleich 1997). A letter reported that Rabbi Jacob Kamenetsky, an expert on Talmudic law, had rejected Feinstein's decision, and Bleich added this: "[It is] not at all surprising. Indeed, I would be hard pressed to name any rabbinic authority of stature who was in agreement" (Bleich 1997, p. 80).

Bleich's own opinion concerning the separation of conjoined twins seemed to be that medical intervention should not be attempted, even in cases in which both twins were certain to die without surgical intervention. Bleich rejected the comparison between conjoined twins and a pregnant woman whose life is endangered by her fetus. In the latter case, the fetus does not have the status of a person. "Homicide is a capital offense whereas feticide is not; hence, the threat against the mother is qualitatively more serious than the threat to the fetus", he wrote. Given that threat, he noted, doctors are permitted to abort the pregnancy (Bleich 1996, p. 109). In the case of conjoined twins, Bleich argued, both lives have equal status. Whereas Koop had claimed that "the four-chambered heart 'definitely belongs to one of the twins' exclusively", Bleich countered, writing, "It appears to this writer that Dr. Koop's statement that the heart belonged to one of the twins' is conclusory in nature and not supported by any halakhically relevant evidence" (Bleich 1996, p. 102). Since neither twin could be considered a "victim" of the other, he asserted, both twins should be left to die a natural death.

Bleich's position - that one should allow both babies to die-may seem shocking to some readers, but this disagreement reflects the legal processes that remain inscribed in Jewish practice today, and it underscores the complexity of the situation that led the Lakewood couple to seek halakhic assistance from Feinstein in the first place. Moreover, it is significant that, despite his disagreement with Feinstein, Bleich still attempted to understand Feinstein's reasoning. This demonstrates his respect for the diversity of results that may emerge from the halakhic process.

\section{Conclusion}

The 1977 case of the Lakewood conjoined twins represents a fascinating moment in history, and it offers insight into the approaches to medicine by prominent doctors, politicians, laypeople, and theologians from a variety of religions. ${ }^{34}$ In the only

\footnotetext{
${ }^{34}$ See Annas (1987, 2001a, b), Anonymous (2008, 2009, 2012, n.d.) ["The C. Everett Koop Papers"], Bleich (1996, 1997, 2000), Brandon (1994), Brown (2012), Crane (2012, 2013) Davis (2011), Easterbrook (2009), England and Wales Court of Appeal (Civil Division) Decisions (2000a, b), Enker (2008),
} 
two books on Koop-his autobiography and the much briefer biography by Easterbrook-his involvement in the case of the conjoined twins was featured prominently. When Tendler wrote a book about his halakhic collaboration with his father-in-law, his discussion of the case of the conjoined twins stands out as extremely significant. Whereas all other essays in the book are translations of the existing responsa written by Feinstein, the account of the 1977 case is Tendler's original composition. ${ }^{35}$

Donald Drake, the key medical reporter whose coverage of the event provided most of the primary source material known about the Lakewood case, turned his experience of covering the case into a play, Choice. A reading of the play premiered in 2012 in Philadelphia, as reported in a February 12, 2012 article by Dotty Brown, "C. Everett Koop and a Choice Between Lives", in the Jewish Daily Forward. Her article highlighted the fact that Koop, one of the key participants in the drama, was in the audience at that time.

It is to be expected in a fictionalization of history that the drama differs from the historical events of this case. In Choice, Drake used the outline of the events, but created fictional conflicts among the Jewish participants where, in reality, there had been none. As Brown noted, Drake's play presents a religious Jewish couple who are torn apart by the decision they must make with regard to their conjoined twin daughters. ${ }^{36}$ The fictionalized Koop, as the surgeon, tells them that since the girls share one-and-a-half hearts, only one child can live, while the other, without the shared heart, will die. Drama is added when the parents are faced with making a choice between the children - a sure death sentence for one so that the other may live. They wrestle with the questions: "And is killing one to possibly save the other justified? Is it a violation of Jewish law? Should the babies live joined for as long as they can?" However, as Brown notes, "In real life, the choice was wrenching but ultimately clear. Saving a life is paramount. And one of the babies contained the greater share of the heart. But Drake uses the liberty of art to make the decision even more fraught, with the couple warring against each other, the hospital staff threatening to boycott [the surgery], and the rabbis disagreeing on Jewish law".

As we have seen, none of the disagreements inherent in Drake's play existed in the real situation. In naming his play Choice, Drake was referring to the multiple options that existed in the decision-making process for the parents of the twins. Should they do nothing and see how nature would take its course? In the play, the

\footnotetext{
Footnote 34 (continued)

Halperin (2001), Harari (2008), Jachter (2012), Kattner (1985), Kuhse and Singer (1985), Levy (2009), Meehan (1978), Morrison (2013) (note that this is in Koop's obituary in the Philadelphia Daily News), Pfeffer (2015), Phang (2001b), Raffensperger (1997), Simmons (n.d.), Steinmetz (n.d.), Tatz (2001, p. 197), Thaler (2007), Thomasma et al. (1996) and Weinstein (2012).

35 In fact, it is in this book that an entirely new facet of the case is introduced, a purported quote by Koop about his reliance on Feinstein's judgment. Tendler quotes Koop as saying this: "The ethics and morals involved in this decision are too complex for me. I believe they are too complex for you as well. Therefore I referred it to an old rabbi on the Lower East Side of New York. He is a great scholar, a saintly individual. He knows how to answer such questions. When he tells me, I too will know" (Tendler 1996a, p. 130). This statement attributed to Koop has become a popular touchstone in the many later retellings of the story of the Lakewood conjoined twins.

36 All of my discussion of the play is based on Brown's article.
} 
rabbis are in disagreement as to what path to follow, while, in reality, any dissention that occurred was expressed anonymously, years after Feinstein handed down his decision.

In addition, the husband and wife depicted in the play are in disagreement, and they argue about what to do. In reality, however, the Orthodox religious beliefs of the parents were another key factor that explained why they did not dissent about what to do in this situation. Jewish law dictated that they should not assert their personal autonomy, but rather seek rabbinic authority to understand what was to be done. Drake's dramatic rendering introduced conflicts that would be understandable to a modern secular audience; in reality, however, the legalistic character of Orthodox Judaism meant that "choice" was not a paradigm that fit the worldview of the twins' parents.

Drake's decision to title his play Choice highlighted one final, significant component of the 1977 case - namely, that the actors in the case had a choice to make. The importance of this point becomes clear when this case is juxtaposed with the 2000 case of conjoined twins in Britain. There, the parents attempted to reach their own decision based upon their religious beliefs, but the state intervened. In the 1977 case in Lakewood, the parents were able to draw upon precedents in American law that allowed for their privacy and autonomy in determining the medical fate of their children. This level of autonomy has changed over time, even in the United States, where the government is increasingly acting in line with certain religious doctrines.

Moreover, what the 1977 case shows are the circumstances that can rise in a religiously pluralistic country like the United States. Different perspectives are at play, not only within the major American religions regarding matters of life and death, but also within Orthodox Judaism. This includes the conflicting ways of interpreting halakhah. As noted above, this diversity of opinion stems directly from the legal nature of Judaism. The religious identities and affiliations of the doctors, the parents, the nurses, the press, the rabbinic authorities, and even the judges on the bench came into play in determining the outcome of the 1977 case. The public's reception of the case over the years-within both American society and the Orthodox Jewish rabbinic community, in particular-further highlights the complexities of such cases. An understanding of the interplay of law, ethics, and religion in Judaism's confrontation with modern medicine will help to elucidate the competing motivations and values that may drive medical decision-making in the future.

\section{References}

Aird, Ian. 1954. The conjoined twins of Kano. The British Medical Journal 1(4866): 831-837.

Annas, George J. 1987. At law: Siamese twins: Killing one to save the other. The Hastings Center Report 17(2): 27-29.

Annas, George J. 2001a. The limits of law at the limits of life: Lessons from cannibalism, euthanasia, abortion, and the court-ordered killing of one conjoined twin to save the other. Connecticut Law Review 33: 1275-1296.

Annas, George J. 2001b. Conjoined twins: The limits of law at the limits of life. The New England Journal of Medicine 344(14): 1104-1108.

Anonymous. 1957. Siamese twins survive surgery here. The Philadelphia Inquirer. October 6, 1957. http://profiles.nlm.nih.gov/ps/retrieve/ResourceMetadata/QQBBXR. Accessed 16 June 2013. 
Anonymous. 1974. The God-fearing surgeon who separated the twins. People Weekly Magazine. October 7, 1974. http://profiles.nlm.nih.gov/ps/retrieve/Narrative/QQ/p-nid/86/p-docs/true Accessed 16 June 2013.

Anonymous. 2000. British court overrules parents in conjoined twins case. Christianity Today. http:// www.christianitytoday.com/ct/2000/septemberweb-only/25.0c.html Accessed 29 Sept 2013.

Anonymous. 2002. Conjoined twins: Re a down under. Medical Law Review 10(1): 100-102.

Anonymous. 2008. YU medical ethics: Split decision: Separation of conjoined twins in halakha. Transcript of a discussion on medical ethics at Yeshiva University at the blog The Curious Jew. http:// curiousjew.blogspot.com/2008/03/yu-medical-ethics-split-decision.html Accessed 28 Nov 2012.

Anonymous. 2009. Former U.S. Surgeon General reveals he sought advice of Rabbi Moshe Feinstein Zt'1 and other rabbinic laws. Chabad.org via the blog Vos Iz Neias? April 25, 2009. http://www.vosiz neias.com/30674/2009/04/25/hanover-nh-former-us-surgeon-general-reveals-he-sought-advice-ofrabbi-moshe-feinstein-ztl-and-other-rabbinic-laws/ Accessed 13 June 2013.

Anonymous. 2012. Two tablets, one heart. Sermon Resource for Shluchim. The Shluchim Office of Chabad-Lubavitch, Brooklyn, N.Y. http://www.shluchim.org/clil/mailroot/images/File/Weely _Sermons/5772/shavuos/FirstDayShavouosEnglish.pdf. Accessed 16 June 2013.

Anonymous. XXXXa. Rabbi Jack Segal, Rabbi emeritus. https://bethyeshurun.org/welcome/clergy/rabbi -jack-segal-rabbi-emeritus. Accessed 14 Aug 2016.

Anonymous. XXXXb. The C. Everett Koop papers: Congenital birth defects and the medical rights of children: The "Baby Doe" controversy. Profiles in Science, U.S. National Library of Medicine. http://profiles.nlm.nih.gov/ps/retrieve/Narrative/QQ/p-nid/86. Accessed 16 June 2013.

Aronova, Elena. 2009. In search of the soul in science: Medical ethics' appropriation of philosophy of science in the 1970s. History and Philosophy of the Life Sciences 31(1): 5-33.

Batnitzky, Leora. 2011. How Judaism became a religion: An introduction to modern Jewish thought. Princeton: Princeton University Press.

Beecher, Henry K., et al. 1984. A definition of irreversible coma: Report of the ad hoc committee of the Harvard Medical School to examine the definition of brain death. The Journal of the American Medical Association 252(5): 677-679.

Bleich, J.David. 1996. Conjoined twins. Tradition 31(1): 92-125.

Bleich, J.David. 1997. Communications. Tradition 31(4): 81-82.

Bleich, J.David. 2000. The case of the British conjoined twins. Tradition 34(4): 61-78.

Blidstein, Gerald J. 2009. Talmudic ethics and contemporary problematics. The Review of Rabbinic Judaism 12(2): 204-217.

Brand, Itzhak. 2010. Religious medical ethics: A study of the rulings of Rabbi Waldenberg. The Journal of Religious Ethics 38(3): 495-520.

Brandon, Karen. 1994. Doctors who operated on Lakeberg twins faced questions with no easy answers. The Chicago Tribune. 21 Feb 1994.

Breitowitz, Yitzchok A. 1996. How a Rabbi Decides a Medical Halacha Issue: Synopsis of Presentation, Conference on Jewish Medical Ethics, San Francisco, CA, February 18-20, 1996. http://www.jlaw. com/Articles/decide.html Accessed 26 July 2013.

Brown, Dotty. 2012. C. Everett Koop and a Choice Between Lives. The Jewish Daily Forward. February 12, 2012. http://blogs.forward.com/the-arty-semite/151687/c-everett-koop-and-a-choice-betwe en-lives/. Accessed 26 July 2013.

Broyde, Michael J. 2000. The procedures of Jewish law and the path to good-ness and God-ness: Halakhah in the Jewish tradition. The Jurist 60: 25-45.

Broyde, Michael J. 2001. Introduction: Rights and duties in Jewish tradition. In Contrasts in American and Jewish Law, ed. Daniel Pollack, xxiii-xxix. New York: Yeshiva University Press.

Clinton, Bill. 2004. My life. New York: Alfred A. Knopf.

Cover, Robert M. 1987. Obligation: A Jewish jurisprudence of the social order. The Journal of Law and Religion 5(1): 65-74.

Cowley, Christopher. 2003. The conjoined twins and the limits of rationality in applied ethics. Bioethics 17(1): 69-88.

Crane, Jonathan K. 2012. Rethinking Conjoined Twins. CCAR Journal: The Reform Jewish Quarterly 59(1): 125-141.

Crane, Jonathan K. 2013. Narratives and Jewish bioethics. New York: Palgrave Macmillan.

Cypess, Joshua N. 2015. Jewish medical culture: Case studies in end-of-life decision making. Doctoral Dissertation, Brandeis University. 
Davis, Colleen. 2011. Conjoined twins as persons that can be victims of homicide. Medical Law Review 19: 430-466.

Dominus, Susan. 2011. Could conjoined twins share a mind? The New York Times (May 29). http:// www.nytimes.com/2011/05/29/magazine/could-conjoined-twins-share-a-mind.html?pagew anted=all. Accessed 16 June 2013.

Dorff, Elliot N. 1998. Matters of life and death: A Jewish approach to modern medical ethics. Philadelphia: Jewish Publication Society.

Dougherty, Charles. 1993. A life-and-death decision: The Lakeberg twins. Health Progress 16: 30-31.

Drake, Donald C. 1977a. The twins decision: One must die so one can live. The Philadelphia Inquirer, 16 October 1977. Reprinted in Assai 4(1) (February, 2001).

Drake, Donald C. 1977b. The twins decision, part 2: Now one fights for her life. The Philadelphia Inquirer. 20 November 1977. http://profiles.nlm.nih.gov/ps/retrieve/Narrative/QQ/p-nid/86/pdocs/true. Accessed 16 June 2013.

Drake, Donald C. 1978. The twins decision: Baby B's final crisis. The Philadelphia Inquirer. January 12, 1978. http://profiles.nlm.nih.gov/ps/retrieve/Narrative/QQ/p-nid/86/p-docs/true. Accessed 16 June 2013.

Easterbrook, Gregg. 1991. Surgeon Koop: Medicine and the politics of change. Knoxville, TN: Whittle Direct Books.

Easterbrook, Gregg. 2009. A moral precedent for the Siamese Twins Case. Beliefnet. https://www. beliefnet.com/love-family/parenting/2000/09/a-moral-precedent-for-the-siamese-twins-case. aspx. Accessed 16 June 2013.

Elon, Menachem. 1994. Jewish Law: History, sources, principles. 4 volumes, translated from the Hebrew by Bernard Auerbach and Melvin J. Sykes. Philadelphia: Jewish Publication Society.

England and Wales Court of Appeal (Civil Division) Decisions. 2000a. [2000] 3 FCR 577, [2000] HRLR 721, [2000] Lloyd's Rep Med 425, [2000] EWCA Civ 254, (2001) 57 BMLR, [2000] Lloyds Rep Med 425, [2001] UKHRR 1, [2001] 2 WLR 480, [2001] Fam Law 18, [2001] Fam 147, 9 BHRC 261, [2000] 4 All ER 961, [2001] 1 FLR 1. http://www.bailii.org/ew/cases/ EWCA/Civ/2000/254.html. Accessed 16 June 2013.

England and Wales Court of Appeal (Civil Division) Decisions. 2000b. [2000] EWCA Civ 401. http:// court-appeal.vlex.co.uk/vid/-52580003. Accessed 16 June 2013.

Englard, Izhak. 1988. The interaction of morality and Jewish law. The Jewish Law Annual 7: 114-124.

Enker, Arnold. 2008. Severing the conjoined twins: In Re A in Jewish Law. Conference Papers, International Society for the Reform of Criminal Law.

Falk, Ze'ev W. 1994-1995. Jewish religious law in the modern (and postmodern) world. The Journal of Law and Religion 11(2): 465-498.

Fishbane, Simcha. 1990. The Supra-Legal Materials in Rabbi Israel Mayer Hacohen's Mishnah Berurah. In Essays in the Social Scientific Study of Judaism and Jewish Society, eds. Simcha Fishbane and Jack N. Lightstone, with Victor Levin, 203-214. Montreal: Concordia University Press.

Freedman, Benjamin. 1999. Duty and healing: Foundations of a Jewish Bioethic. New York: Routledge.

Freeman, Michael. 2001. Whose life is it anyway? Medical Law Review 9: 259-280.

Gamble, Vanessa Northington. 1997. Under the shadow of Tuskegee: African Americans and health care. American Journal of Public Health 87(11): 1773-1778.

Gamble, Vanessa Northington. 2006. Trust, medical care, and racial and ethnic minorities. In Multicultural medicine and health disparities, ed. David Satcher, Rubens J. Pamies, and Nancy N. Woelfl, 437-448. New York: McGraw Hill.

Glick, Shimon. 2008. The methodology of Jewish medical ethics. In Studies in Jewish medical ethics, ed. Fred Rosner, Henri Goldstein, and Edward Reichman, 36-47. Aalborg: Højers Forlag.

Glick, Shmuel. 2012. Eshnav le-sifrut ha-teshuvot (Window to the responsa literature). New York: Bet ha-midrash le-rabanim be-Amerikah.

Goldsand, Gary, Zahava R.S. Rosenberg, and Michael Gordon. 2001. Bioethics for clinicians 22. Jewish bioethics. Canadian Medical Association Journal 164(2): 219-222.

Golladay, E.S., G. Doyne Williams, Joanna J. Seibert, W.T. Dungan, and Ray Shenefelt. 1982. Dicephalus dipus conjoined twins: A surgical separation and review of previously reported cases. Journal of Pediatric Surgery 17(3): 259-264.

Green, Ronald M. 2005. Foundations of Jewish ethics. In The Blackwell companion to religious ethics, ed. William Schweiker, 166-175. Oxford: Blackwell Publishing Ltd. 
Halperin, Mordechai. 2001. Siamese Twins: Rav Feinstein's Ruling and the Subsequent Controversy. Assia 4(1). http://www.daat.ac.il/daat/kitveyet/assia_english/halperin2-1.htm. Accessed 16 June 2013.

Harari, David et al. 2008. YU Medical Ethics-Split Decision: Separation of Conjoined Twins in Halakha. In the blog The Curious Jew, http://curiousjew.blogspot.com/2008/03/yu-medical-ethic s-split-decision.html. Accessed 15 Mar 2013.

Harris, John. 2001. Human beings, persons, and conjoined twins: An ethical analysis of the judgment in Re A. Medical Law Review 9: 221-236.

Herberg, Will. 1955. Protestant, Catholic, Jew: An essay in American Religious Sociology. Chicago: University of Chicago Press.

Hewson, Barbara. 2001. Killing off Mary: Was the court of appeal right? Medical Law Review 9: 281-298.

In Re Quinlan, 355 A.2d 647, 70 N.J. 10, Supreme Court of New Jersey 10 (1976).

Jachter, Rabbi Chaim. 2012. Separating conjoined twins Gray Matter: Exploring Contemporary Halakhic Challenges, vol. 4, 282-286. Teaneck, NJ: Kol Torah Publications Ltd.

Jackson, Bernard S. 1987. Secular jurisprudence and the philosophy of Jewish law: A commentary on some recent literature. The Jewish Law Annual 6: 3-44.

Jackson, Bernard S. 2008. Jewish law. In The New Oxford companion to law, ed. Peter Cane and Joanne A.F. Conaghan. Oxford: Oxford University Press.

Jospe, Alfred, Leni Yahil, Allan Arkush, and Shmuel Feiner. 2007. Mendelssohn, Moses. Encyclopedia Judaica, Second Edition, Vol. 14, 33-40. https://ketab3.files.wordpress.com/2014/11/encyclopae dia-judaica-v-14-mel-nas.pdf. Accessed 13 May 2019.

Kattner, Joseph F. 1985. OK to kill twin to save other, scholars say. The Legal Intelligencer (March 25, 1985), 1 and 22.

Koop, C.Everett. 1990a. Koop: The memoirs of America's family doctor. New York: Random House.

Koop, C.Everett. 1990b. Decisions at the end of life. Proceedings of the American Philosophical Society 134(3): 230-242.

Kuhse, Helga, and Peter Singer. 1985. Ethics and the handicapped newborn infant. Social Research 52(3): $505-542$.

Lamm, Norman. 2007. Faith \& Doubt: Studies in Traditional Jewish Thought, Third augmented ed. Jersey City, NJ: Ktav Publishing House.

Lasker, Daniel. J. XXXX. When the Rabbis meet the doctors: How Medical Halakhah is made. http://hsf. bgu.ac.il/cjt/files/electures/medicalhalakh1.htm. Accessed 14 May 2006.

Latkovic, Mark S. 2001. A Catholic moral perspective on the separation of the conjoined twins Jodie and Mary: A survey and critique. National Catholic Bioethics Quarterly 1(4): 1-30.

Lepicard, Etienne. 2009. Reception of National Socialist "euthanasia" vs. "human experimentation" and the transformation of medical ethics into bioethics, 1947-1980s. Korot: The Israel Journey of the History of Medicine and Science 19: 65-81.

Levene, Nancy. 2005. From law to ethics... and back. In The Blackwell companion to religious ethics, ed. William Schweiker, 188-196. Oxford: Blackwell Publishing Ltd.

Levin, Faitel. 1987. Halacha, medical science, and technology: Perspectives on contemporary Halacha issues. New York: Moznaim Publishing Corporation.

Levy, Allison. 2009. Former surgeon general looks back at hallmark case influenced by rabbinic law. Chabad.org/News (April 29). http://www.chabad.org/news/article_cdo/aid/880801/jewish/SurgeonGeneral-Addresses-Dartmouth-Students.htm. Accessed 16 June 2013.

Lichtenstein, Aharon. 1975. Does Jewish tradition recognize an ethic independent of halakha? Modern Jewish ethics: Theory and practice. Columbus: Ohio State University Press.

Low, W., and J.David Bleich. 1997. Communications: Conjoined twins. Tradition: A Journal 31(4): 80-82.

Lowry, Joseph F. Separated twins well, leave hospital for home. The Philadelphia Evening Bulletin. October 22, 1957. http://profiles.nlm.nih.gov/ps/retrieve/ResourceMetadata/QQBBXS. Accessed 26 July 2013.

Magid, Shaul. 2005. Ethics differentiated from the law. In The Blackwell companion to religious ethics, ed. William Schweiker, 176-187. Oxford: Blackwell Publishing Ltd.

McEwan, Jenny. 2001. Murder by design: The 'feel-good factor' and the criminal law. Medical Law Review 9: 246-258.

Meehan, Francis X. 1978. The Siamese twin operation and contemporary Catholic medical ethics. The Linacre Quarterly 45(2): 157-164. 
Moodie, Michael, et al. 1993. Symposium on religious law: Roman Catholic, Islamic, and Jewish treatment of familial issues, including education, abortion, in vitro fertilization, prenuptial agreements, contraception, and marital fraud. The Loyola of Los Angeles International Comparative Law Journal 16(1): 9-106.

Morrison, John F. 2013. C. Everett Koop, former surgeon general with Philly ties. The Philadelphia Daily News. February 26, 2013. http://www.philly.com/philly/obituaries/20130226_C_Everett_Koop_ former_surgeon_general_with_Philly_ties.html?arc404=true. Accessed 22 Aug 2018.

Nason, Donna. 1982. America's compassionate chief physician. The Saturday Evening Post (May-June): 16-18.

Paris, John J., and A.C. Elias-Jones. 2001. "Do we murder Mary to save Jodie?" An ethical analysis of the separation of the manchester Conjoined twins. Postgraduate Medical Journal 77: 593-598.

Pepper, C.K. 1967. Ethical and moral considerations in the separation of conjoined twins: Summary of two dialogues between physicians and clergymen. Birth Defects Original Article Series 3(1): 128-134.

Pfeffer, Yehoshua. 2015. Parshas Pinchas-The laws of rodef: The matter of conjoined twins. The International Beis Horaah: The Institute for Dayanim. http://dinonline.org/2015/07/05/parshas-pinchas-thelaws-of-rodef-the-matter-of-conjoined-twins/. Accessed 22 Aug 2018.

Phang, Andrew. 2001a. Conjoined twins: The limits of reason and the transcendent hope: Part two. Law \& Justice: The Christian Law Review 147: 89-113.

Phang, Andrew. 2001b. Conjoined twins: The limits of reason and the transcendent hope: Part one. Law \& Justice: The Christian Law Review 146: 38-56.

Putnam, Hilary. 2005. Jewish ethics? In The Blackwell companion to religious ethics, ed. William Schweiker, 159-165. Oxford: Blackwell Publishing Ltd.

Raffensperger, J. 1997. A philosophical approach to conjoined twins. Pediatric Surgery International 12(4): 249-255.

Rees, A.E.J., G.M. Vujanic, and W.M. Williams. 1993. Epidemic of conjoined twins in Cardiff. The British Journal of Obstetrics and Gynaecology 100(4): 388-391.

Resnicoff, Steven H. 2006. Supplying human body parts: A Jewish law perspective. The DePaul Law Review 55: 851-874.

Sagi, Avi. 1994. The punishment of Amalek in Jewish tradition: Coping with the moral problem. The Harvard Theological Review 87(3): 323-346.

Sarna, Jonathan D. 1990. Is Judaism compatible with American civil religion? The problem of Christmas and the 'national faith'. In Religion and the life of the nation, ed. Rowland A. Sherrill, 154-173. Urbana: University of Illinois Press.

Shapiro, Howard S. Joined at heart, twins severed. The Philadelphia Inquirer: Section A, 1 and 7. October 12, 1977. http://profiles.nlm.nih.gov/ps/retrieve/Narrative/QQ/p-nid/86/p-docs/true. Accessed 1 Jan 2017.

Sheldon, Sally, and Stephen Wilkinson. 2001. 'On the Sharpest Horns of a Dilemma': Re A (Conjoined Twins). Medical Law Review 9(3): 201-207.

Simmons, Shraga. XXXX. Siamese Twins. Aish.com. http://www.aish.com/j1/i/mn/48932057.html. Accessed 16 June 2013.

Sinclair, Daniel B. 1992. The interaction between law and morality in Jewish law in the areas of feticide and killing a terminally ill individual. Criminal Justice Ethics 11(2): 76-84.

Snider, Arthur J. 1974. Doctor trusts in power of God: Surgeon who separated Siamese twins prays for guidance before each operation. The Chicago Daily News. September 23, 1974. https://profiles.nlm.nih. gov/ps/access/QQBBXG.pdf. Accessed 23 Aug 2018.

Solomon, W.David. 1995. Ethics. In Encyclopedia of bioethics, vol. 1, 3rd ed, ed. Warren T. Reich. New York: Macmillan Publishing Company.

Statman, Daniel. 2010. Halakha and morality: A few methodological considerations. The Journal of Textual Reasoning 6(1): 1-16.

Steinmetz, Chaim. XXXX. Separating conjoined twins. Jewish Law: Commentary. http://www.jlaw.com/ Commentary/cojoinedtwins.html. Accessed 15 Mar 2013.

Sullivan, Winnifred Fallers. 2005. Law and religion. In The Blackwell companion to religious ethics, ed. William Schweiker, 104-111. Oxford: Blackwell Publishing Ltd.

Summers, Robert S. 1978. Two types of substantive reasons: The core of a theory of common-law justification. The Cornell Law Review 63: 707.

Supreme Court of the United States. 1973. Roe v. Wade, 410 U.S. 113, 93 S. Ct. 705, 35 L. Ed. 2 d 147.

Tatz, Akiva. 2001. Dangerous disease and dangerous therapy in Jewish medical ethics: Principles and practice. Southfield, MI: Targum Press.

Tendler, Moshe Dovid. 1996a. Unpublished Responsum: 'So One May Live'. Moshe Feinstein, Responsa of Rav Moshe Feinstein: Care of the Critically Ill, translated and annotated by Moshe Dovid Tendler, vol. 1, 125-133. Brooklyn, NY: Ktav Publishing House. 
Tendler, Moshe Dovid. 1996b. Preface. In Moshe Feinstein, Responsa of Rav Moshe Feinstein: Volume 1: Care of the Critically Ill, translated and annotated by Moshe Dovid Tendler. Brooklyn, N.Y.: Ktav Publishing House. vii-viii.

Teutsch, David A. 2005. Bioethics: Reinvigorating the practice of contemporary Jewish ethics. Wyncote, PA: Reconstructionist Rabbinical College Press.

Thaler, Devorah. 2007. Siamese twins: Together forever? Derech HaTeva: A Journal of Torah and Science (June 4): 54-56. http://www.yutorah.org/lectures/lecture.cfm/724363/devorah-thaler/siamese-twins -together-forever-l. Accessed 23 Aug 2018.

Thomasma, David C., Jonathan Muraskas, Patricia A. Marshall, Thomas Myers, Paul Tomich, and James A. O'Neill Jr. 1996. The ethics of caring for conjoined twins: The Lakeberg case. The Hastings Center Report 26(4): 4-12.

Uniacke, Suzanne. 2001. Was Mary’s death murder? Medical Law Review 9(3): 208-220.

University of Maryland Medical Center. XXXX. Conjoined Twins. http://umm.edu/programs/conjoinedtwins/facts-about-the-twins. Accessed 2 Aug 2016.

USLegal.com. Necessity law and legal definition. http://definitions.uslegal.com/n/necessity. Accessed 1 Apr 2015.

USLegal.com. Justification Law and Legal Definition. http://definitions.uslegal.com/j/justification/. Accessed 1 Apr 2015.

Ward, Brooke, and Robert Walker, LJJ. 2000. In Re A (Children) (Conjoined Twins: Surgical Separation) [2001] Fam 147, Court of Appeal.

Washofsky, Mark. 2012. The woodchopper revisited: On analogy, halakhah, and Jewish bioethics. In Medical Frontiers and Jewish law, ed. Walter Jacob, 1-62. Pittsburgh: Freehof Institute for Progressive Halakhah.

Washofsky, Mark. 2007. On the absence of method in Jewish bioethics: Rabbi Yehezkel Landau on autopsy. In Jewish Law Association Studies XVII: Studies in Mediaeval Halakhah in Honor of Stephen M. Passamaneck, eds. Alyssa M. Gray and Bernard S. Jackson, Vol. 1, single issue, 254-278. Liverpool: Deborah Charles Publications.

Watt, Helen. 2001. Conjoined twins: Separation as mutilation. Medical Law Review 9(3): 237-245.

Watt, Helen. 2012. Bodily invasions: When side effects are morally conclusive. Catholic Medical Quarterly 62(3): 34-36.

Weingarten, Michael. 2002. Jewish medical ethics and halakhah. The Israel Medical Association Journal 4: $725-726$

Weinstein, Anna. 2012. Her Sister's Keeper. Derech HaTeva: A Journal of Torah and Science (April 24), 78-80. download.yutorah.org/2012/1053/774741.pdf. Accessed 23 Aug 2018.

Wenger, Beth S. 1998. Mitzvah and medicine: Gender, assimilation, and the scientific defense of 'family purity'. Jewish Social Studies 5(1-2): 177-202.

Wenkel, David H. 2006. Separation of conjoined twins and the principle of double effect. Christian Bioethics: Non-Ecumenical Studies in Medical Morality 12(3): 291-300.

Woolf, Jeffrey R. 2009. 'La'Avodat Bor'o': The body in the Shulhan Arukh of R. Joseph Caro. In The Jewish Body: Corporeality, society, and identity in the renaissance and early modern period, ed. Giuseppe Veltri and Maria Diemling, 157-178. Leiden: Brill.

Wyszynski, Diego F. 2001. Dysmorphology in the Bible and the Talmud. Teratology 64: 221-225.

Zohar, No'am J. 1997. Alternatives in Jewish Bioethics. Albany: State University of New York Press.

Publisher's Note Springer Nature remains neutral with regard to jurisdictional claims in published maps and institutional affiliations.

Joshua Cypess is a researcher and consultant in Jewish sociology for The Cypess Group, an independent consulting organization. He holds a Ph.D. from the Department of Near Eastern and Judaic Studies at Brandeis University, an M.A. in Sociology from Brandeis, an M.A. in Jewish Philosophy from the Bernard Revel Graduate School of Jewish Studies at Yeshiva University, and a B.A. in Anthropology from Princeton University. A Wexner Graduate Fellow, he served previously as Assistant Rabbi of Congregation Kehilath Jeshurun (New York) and as Rabbi of the Young Israel of New Haven, CT. It was his work as a pulpit rabbi, in which position he encountered numerous difficult end-of-life cases, that led him to research in this area. 